ARTICLE

\title{
Evidence for ligand- and solvent-induced disproportionation of uranium(IV)
}

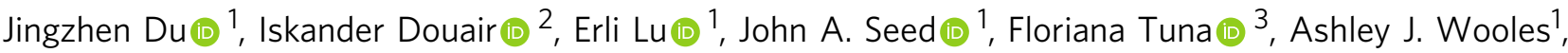
Laurent Maron (10) ${ }^{2 \times} \&$ Stephen T. Liddle (i) ${ }^{1 \times}$

Disproportionation, where a chemical element converts its oxidation state to two different ones, one higher and one lower, underpins the fundamental chemistry of metal ions. The overwhelming majority of uranium disproportionations involve uranium(III) and (V), with a singular example of uranium(IV) to uranium(V/III) disproportionation known, involving a nitride to imido/triflate transformation. Here, we report a conceptually opposite disproportionation of uranium(IV)-imido complexes to uranium(V)-nitride/uranium(III)-amide mixtures. This is facilitated by benzene, but not toluene, since benzene engages in a redox reaction with the uranium(III)-amide product to give uranium(IV)-amide and reduced arene. These disproportionations occur with potassium, rubidium, and cesium counter cations, but not lithium or sodium, reflecting the stability of the corresponding alkali metal-arene byproducts. This reveals an exceptional level of ligand- and solvent-control over a key thermodynamic property of uranium, and is complementary to isolobal uranium(V)-oxo disproportionations, suggesting a potentially wider prevalence possibly with broad implications for the chemistry of uranium.

\footnotetext{
${ }^{1}$ Department of Chemistry, The University of Manchester, Manchester, UK. ${ }^{2}$ LPCNO, CNRS \& INSA, Université Paul Sabatier, Toulouse, France. ${ }^{3}$ Department of Chemistry and Photon Science Institute, The University of Manchester, Manchester, UK.凶email: laurent.maron@irsamc.ups-tlse.fr; steve.liddle@manchester.ac.uk
} 
$\mathrm{D}$ isproportionation, where an ion in an oxidation state converts to ions with two different oxidation states, one higher and one lower, has fundamentally underpinned and defined the chemistry of metal ions for over two centuries ${ }^{1,2}$. Disproportionation of uranium was established 96 years ago ${ }^{3,4}$, and the status quo remained unchanged over seven decades ${ }^{5,6}$, where uranium(V) disproportionates to uranium(IV) and (VI), Eq. (1), and uranium(III) disproportionates to uranium(0) and (IV), Eq. (2). These intrinsic disproportionations, unless kinetically blocked, occur over a wide range of solvents, supporting ligands, and synthetic ${ }^{7-9}$ and environmental scenarios ${ }^{10,11}$, reflecting the inherent thermodynamic instability of these two uranium oxidation states.

$$
\begin{gathered}
2 \mathrm{U}^{\mathrm{V}}\left(5 \mathrm{f}^{1}\right) \rightarrow \mathrm{U}^{\mathrm{IV}}\left(5 \mathrm{f}^{2}\right)+\mathrm{U}^{\mathrm{VI}}\left(5 \mathrm{f}^{0}\right),(\text { est. 1925) } \\
4 \mathrm{U}^{\mathrm{III}}\left(5 \mathrm{f}^{3}\right) \rightarrow 1 \mathrm{U}^{0}\left(7 \mathrm{~s}^{2} 6 \mathrm{~d}^{1} 5 \mathrm{f}^{3}\right)+3 \mathrm{U}^{\mathrm{IV}}\left(5 \mathrm{f}^{2}\right),(\text { est. } 1953) \\
2 \mathrm{U}^{\mathrm{IV}}\left(5 \mathrm{f}^{2}\right) \rightarrow \mathrm{U}^{\mathrm{III}}\left(5 \mathrm{f}^{3}\right)+\mathrm{U}^{\mathrm{V}}\left(5 \mathrm{f}^{1}\right),(\text { est. } 2016 \text { and this work })
\end{gathered}
$$

In contrast to uranium(III) and (V), uranium(IV) and (VI) are conversely regarded as the most stable oxidation states of uranium in virtually all solvent media and ligand environments ${ }^{7-13}$. Indeed, the inherent thermodynamic properties that underpin the redox processes of each oxidation state of uranium are arguably often little changed by the chemical environment defined by ligands and solvent, and they are usually at best kinetically suppressed or contained rather than being decisively materially altered. Thus, whilst uranium(III) and (V) intrinsically engage in disproportionation reactions unless kinetically blocked, disproportionation of uranium(VI) has never been demonstrated. Only as recently as 2016 was uranium(IV) discovered to be capable of disproportionating to uranium(III/V), specifically where a bridging diuranium(IV)-nitride complex reacted with methyl-triflate to give a uranium(III)-triflate and a uranium(V)imido complex, Equation (3) ${ }^{14}$. However, the factors that govern that remarkable example of uranium(IV) disproportionation remain unknown.

Here, we report an example of uranium(IV) disproportionation to uranium(III) and (V) (Eq. 3). Deprotonation of a uranium (IV)-amide to give -imido derivatives promotes, with mild heating, disproportionation to the corresponding uranium(III)-amide and uranium(V)-nitride complexes for three alkali metal salts in benzene, but not toluene, solvent. This reaction is conceptually the reverse reaction to the above example, namely imido to nitride/amide as opposed to nitride to imido/triflate. The disproportionation reaction reported here suggests an unusual level of external control over the thermodynamic properties of uranium, further diminishing the general imperviousness of uranium (IV) with respect to (III) and $(\mathrm{V})^{15}$, and our results provide insight into the factors that are dictating the reactivity. The reactivity outlined here has parallels to that of uranyl $(\mathrm{V})^{10,11}$, possibly suggesting a potentially wider prevalence in highly radiolytic and environmental scenarios ${ }^{16}$.

\section{Results}

Synthetic considerations. We reported previously ${ }^{17}$ that the uranium(IV)-amide complex [ $\mathrm{U}^{\mathrm{IV}}\left(\right.$ Tren $\left.^{\mathrm{TIPS}}\right)\left(\mathrm{NH}_{2}\right)$ ] $\left(\mathbf{1}\right.$, Tren ${ }^{\mathrm{TIPS}}$ $\left.=\left\{\mathrm{N}\left(\mathrm{CH}_{2} \mathrm{CH}_{2} \mathrm{NSiPr}_{3}{ }_{3}\right)_{3}\right\}^{3-}\right)$ can be deprotonated by alkali metal alkyl reagents to produce the pink uranium(IV)-imido dimers $\left[\left\{\mathrm{U}^{\mathrm{IV}}\left(\mathrm{Tren}^{\mathrm{TIPS}}\right)(\mu-\mathrm{NH})(\mu-\mathrm{M})\right\}_{2}\right](\mathbf{2 M}, \mathrm{M}=\mathrm{Li}, \mathrm{Na}, \mathrm{K}, \mathrm{Rb}, \mathrm{Cs})$, Fig. 1, which are insoluble in benzene or toluene at ambient conditions. However, $\mathbf{2} \mathbf{M}$ can be cleaved by addition of the capping agent $\mathrm{N}\left(\mathrm{CH}_{2} \mathrm{CH}_{2} \mathrm{NMe}_{2}\right)_{3}\left(\mathrm{Me}_{6}\right.$-Tren), producing the uranium(IV)-imido monomers $\left[\mathrm{U}^{\mathrm{IV}}\left(\operatorname{Tren}^{\mathrm{TIPS}}\right)(\mu-\mathrm{NH})(\mu-\mathrm{M})\right.$
$\left(\mathrm{Me}_{6}\right.$-Tren)] (3M) in crystalline yields ranging from 35 to $76 \%$, Fig. 1. Complexes $\mathbf{3 M}$ are relatively more soluble in benzene or toluene than $\mathbf{2 M}$, rendering solution-state characterisation spectroscopically possible. Alternatively, $\mathbf{3 M}$ can be prepared from $\mathbf{1}$ in a one-pot reaction instead of separate metallation then capping steps. Throughout both these reaction sequences the oxidation state of uranium remains unchanged at +4 , and these reactions all work in benzene or toluene solvents. During the course of our study, we investigated the effect of thermolysis, and found that moderate heating $\left(80^{\circ} \mathrm{C}\right)$ of reaction mixtures of $\mathbf{1}$ and potassium, rubidium, or caesium alkyls in benzene did not afford $\mathbf{2 K}$, $\mathbf{2} \mathbf{R b}$, and $\mathbf{2 C s}$, respectively. Instead, a different outcome was observed, and the dark red uranium $(\mathrm{V})$-nitride dimers $\left[\left\{\mathrm{U}^{\mathrm{V}}\right.\right.$ $\left(\right.$ Tren $\left.\left.\left.^{\text {TIPS }}\right)(\mu-\mathrm{N})(\mu-\mathrm{M})\right\}_{2}\right](\mathbf{4 M}, \mathrm{M}=\mathrm{K}, \mathrm{Rb}, \mathrm{Cs})^{18,19}$ were isolated in crystalline yields of $18-30 \%$ (50\% maximum yield for disproportionation reactions suggested by a uranium(V) product void of a N-H linkage, see below), Fig. 1. Given their structural similarities to $\mathbf{2 K} / \mathbf{R b} / \mathbf{C s}$, in order to enable meaningful comparisons to be made to monomeric $3 \mathbf{K} / \mathbf{R b} / \mathbf{C s}$ and further confirm the identities of $4 \mathbf{K} / \mathbf{R b} / \mathbf{C s}$, we converted the latter dimeric trio to the dark red uranium $(\mathrm{V})$-nitride monomers $\left[\mathrm{U}^{\mathrm{V}}\right.$ (Tren$\left.{ }^{\text {TIPS }}\right)(\mu-\mathrm{N})(\mu-\mathrm{M})\left(\mathrm{Me}_{6}-\right.$ Tren $\left.)\right](5 \mathrm{M}, \mathrm{M}=\mathrm{K}, \mathrm{Rb}, \mathrm{Cs})$, and isolated them in crystalline yields of $46-76 \%$. Fig. 1 . In contrast, treatment of 1 with lithium and sodium alkyls does not furnish $4 \mathrm{Li}$ and $4 \mathrm{Na}$, and instead $2 \mathrm{Li}$ and $2 \mathrm{Na}$ are consistently isolated. To complete and provide a calibrated $\mathbf{5} \mathbf{M}$ series, we treated dimeric $4 \mathrm{Li}$ and $4 \mathrm{Na}$, prepared by an established procedure ${ }^{18}$, with two equivalents of $\mathrm{Me}_{6}$-Tren to produce monomeric $5 \mathrm{Li}$ and $5 \mathrm{Na}$. The NMR and IR spectra of $\mathbf{3} \mathbf{M}$ and $\mathbf{5} \mathbf{M}$ are consistent with their formulations (Supplementary Figs. 1-25).

Crystallographic characterisation. The characterisation data and crystallographic unit cell checks for $4 \mathbf{K} / \mathbf{R b} / \mathbf{C s}$ produced by disproportionation match those of authentic samples ${ }^{18-20}$. The solid-state structures of the $\mathbf{3 M}$ and $\mathbf{5 M}$ series were determined, confirming their formulations, Figs. 2 and 3 (Supplementary Tables 1-6). For each complex, a triamidoamine-uranium component is bound to a central nitrogen, that resides in the pocket defined by the Tren ${ }^{\text {TIPS }}$ ligand, with that nitrogen atom bridging to a $\mathrm{Me}_{6}$-Tren-capped alkali metal. The salient, key difference between the $\mathbf{3} \mathbf{M}$ and $\mathbf{5 M}$ series is the presence of a hydrogen atom on the central nitrogen of the $\mathbf{3} \mathbf{M}$ imido complexes, whereas no hydrogen atom is present in the $\mathbf{5 M}$ nitride series, resulting in decisively different, and characteristic, $\mathrm{U}-\mathrm{N}_{\text {imido }}$ bond lengths that average $2.007 \AA$ (range: $1.979(4)-2.070(4) \AA$ ) for the $3 \mathrm{M}$ series and shorter $\mathrm{U}-\mathrm{N}_{\text {nitride }}$ distances averaging $1.810 \AA$ (range: 1.792 (4) $-1.823(3) \AA$ ) for the $5 \mathrm{M}$ complexes. For comparison, the U$\mathrm{N}_{\text {imido }}$ distances in the $2 \mathrm{M}$ series span the range $2.042(3)-2.135$ (3) $\AA^{17}$, uranium(V)-nitride complexes of the form $\left[\mathrm{U}^{\mathrm{V}}\right.$ (Tren-

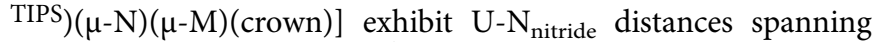
the range $1.803(5)-1.840(3) \AA^{18,19,21}$, and the sum of the covalent radii for doubly and triply bonded uranium and nitrogen are 1.94 and $1.72 \AA$, respectively ${ }^{22}$. Notably, the U-N-M angles span a larger range for the $\mathbf{3 M}$ series $\left(141.01(19)-175.8(2)^{\circ}\right)$ compared to the $5 \mathbf{M}$ series $\left(155.8(3)-177.66(18)^{\circ}\right)$, consistent with the nitride ligand being a harder and less flexible ligand than imido.

Magnetism and spectroscopic characterisation. Variabletemperature superconducting quantum interference device (SQUID) magnetic and UV/Vis/NIR and NMR spectroscopic data for the $\mathbf{3 M}$ and $\mathbf{5 M}$ series confirm their formal +4 and +5 uranium oxidation states, respectively (Supplementary Figs. 26-35 and Table 7). Specifically, the data for powdered samples of the $3 \mathrm{M}$ series reveal magnetic moments over the range 2.75-3.12 $\mu_{\mathrm{B}}$ at $300 \mathrm{~K}$, Fig. $4 \mathrm{a}$. These values are lower than the theoretical 


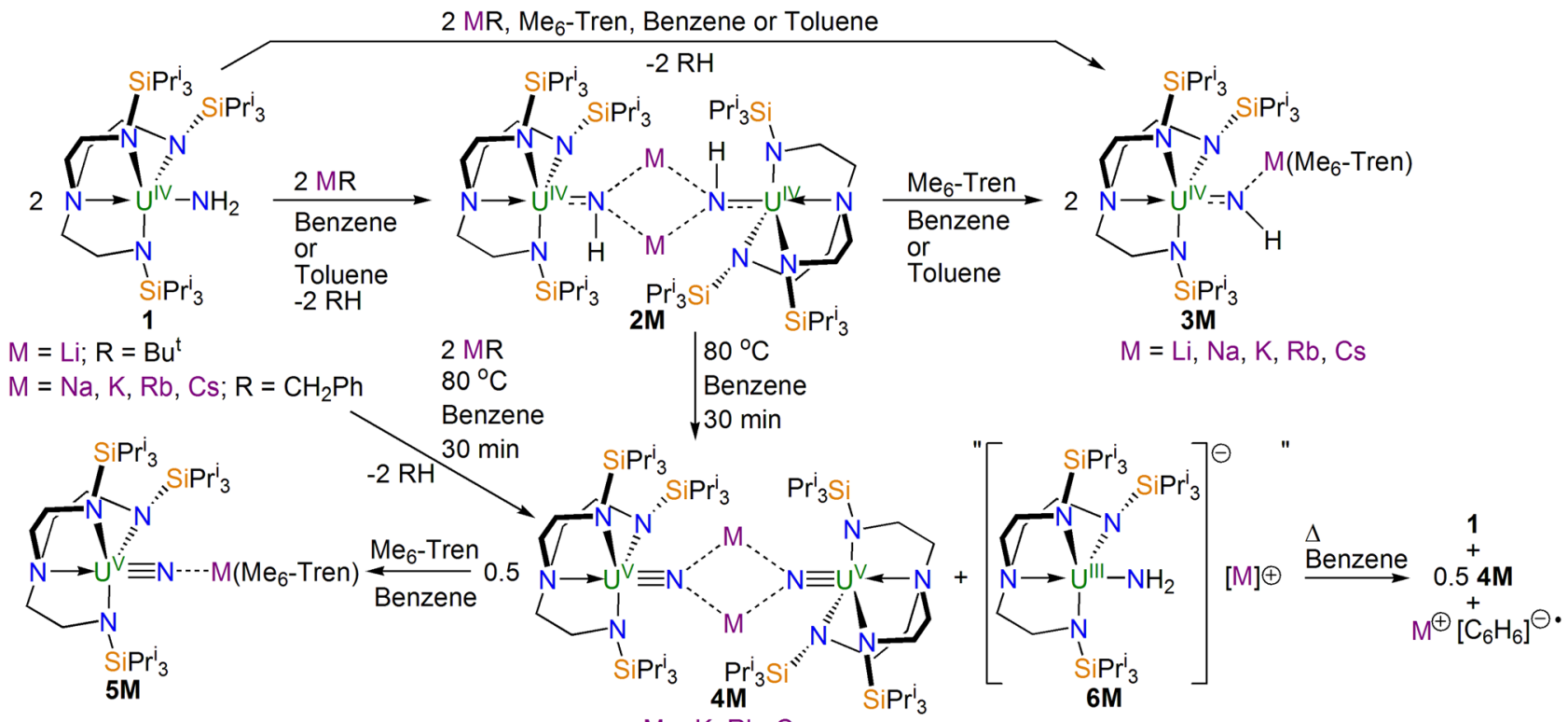

Fig. 1 Synthesis of $\mathbf{2} \mathbf{M}-\mathbf{6} \mathbf{M}$. Complex $\mathbf{1}$ is deprotonated by organo-alkali metal reagents to afford the imido dimers $\mathbf{2} \mathbf{M}$. The imido dimers $\mathbf{2} \mathbf{M}$ can be converted to the imido monomers $\mathbf{3} \mathbf{M}$ by addition of $\mathbf{M e}_{6}$-Tren. Either isolated or in situ prepared $\mathbf{2} \mathbf{M}$ when heated in benzene afford the nitride dimers $\mathbf{4 M}$, which can be converted to the nitride monomers $\mathbf{5} \mathbf{M}$ by addition of $\mathbf{M e}_{6}$-Tren. Complexes $\mathbf{6} \mathbf{M}$ were not isolated, but their oxidation product, $\mathbf{1}$, was isolated.

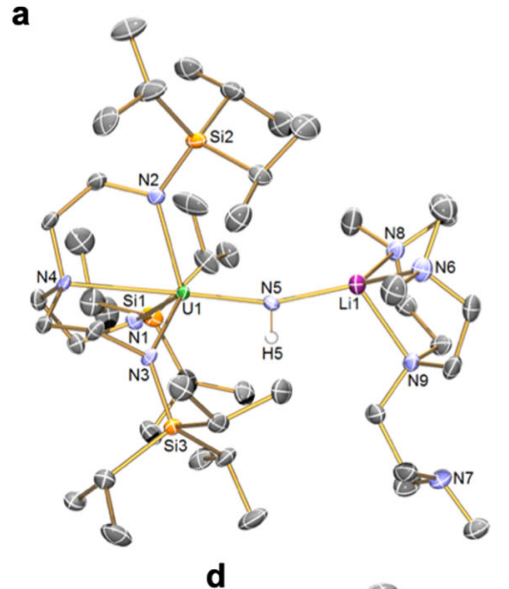

d b

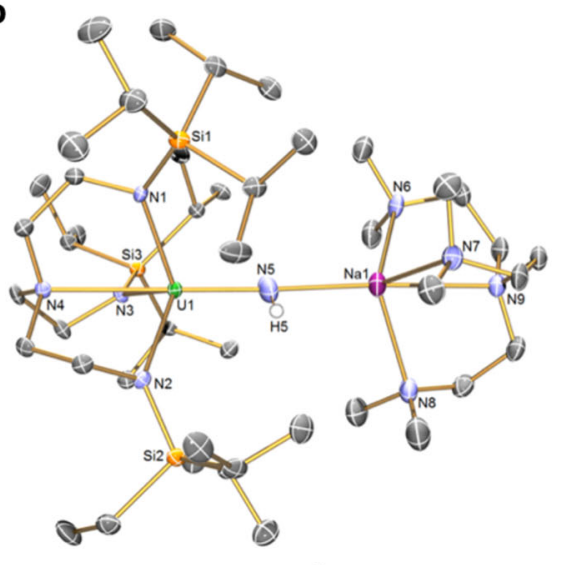

c

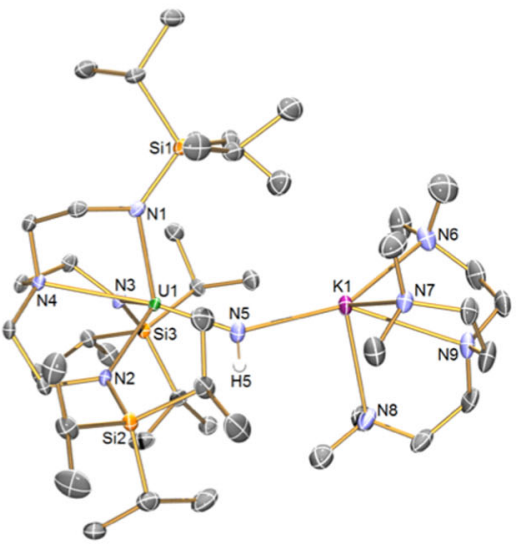

e

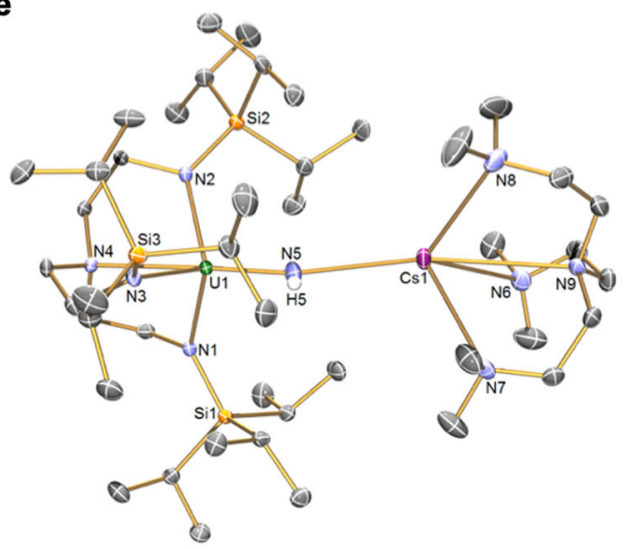

Fig. 2 Solid-state single crystal structures of uranium(IV)-imido (3M) complexes at $150 \mathrm{~K}$ with $\mathbf{4 0} \%$ probability displacement ellipsoids. a complex 3Li. b complex $\mathbf{3} \mathbf{N a}$. c complex $\mathbf{3 K}$. d complex $\mathbf{3} \mathbf{R b}$. e complex $\mathbf{3} \mathbf{C s}$. In each case all non-imido hydrogen atoms, lattice solvent molecules, and disorder components are omitted for clarity. 
a

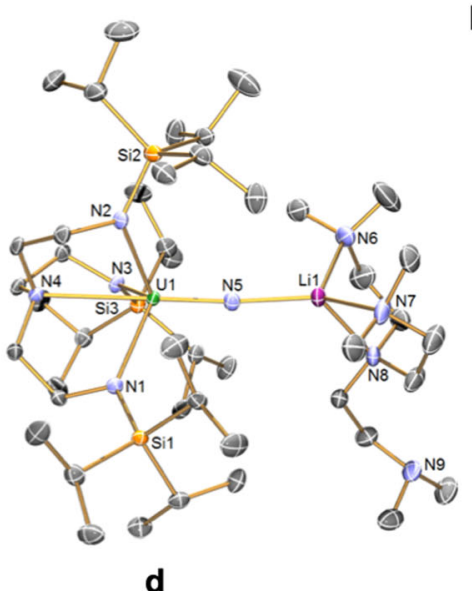

b

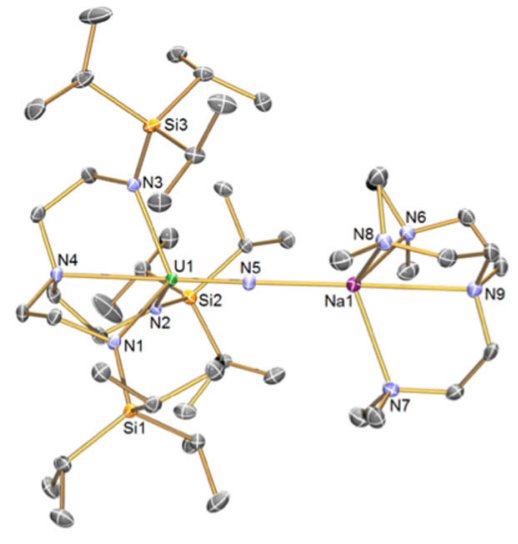

C

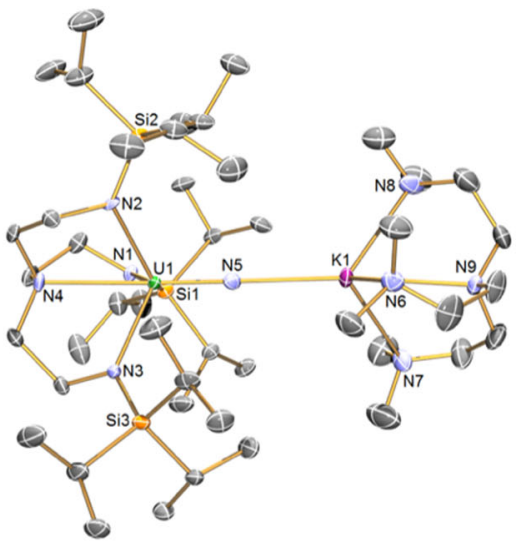

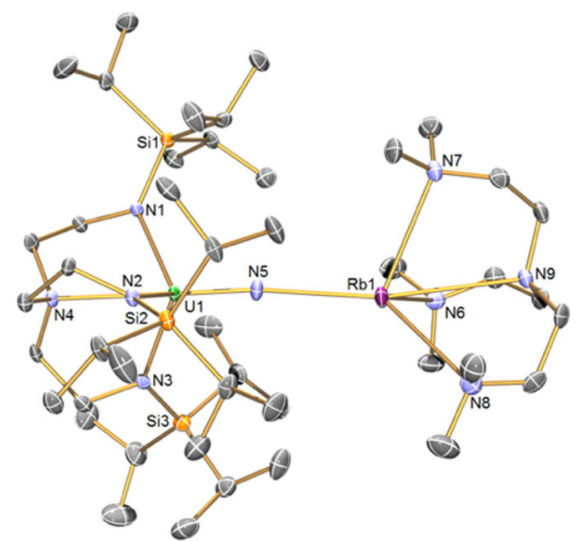

e

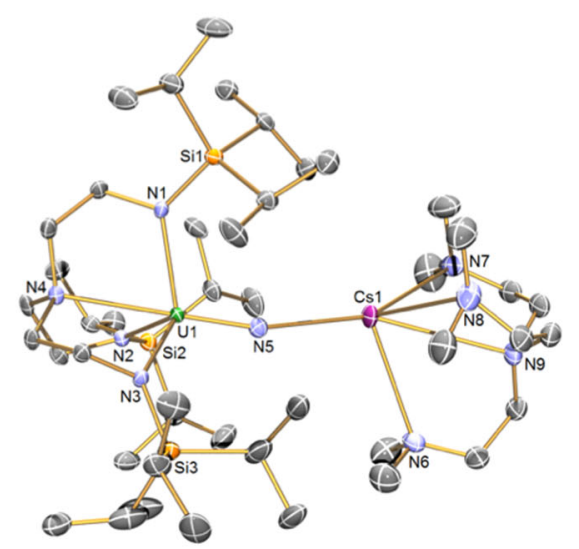

Fig. 3 Solid-state single crystal structures of uranium(V)-nitrides (5M) at $150 \mathrm{~K}$ with $\mathbf{4 0 \%}$ probability displacement ellipsoids. a complex $\mathbf{5 L i}$. b complex $\mathbf{5} \mathbf{N a}$. c complex $\mathbf{5 K}$. $\mathbf{d}$ complex $\mathbf{5} \mathbf{R b}$. e complex $\mathbf{5} \mathbf{C s}$. In each case all non-imido hydrogen atoms, lattice solvent molecules, and disorder components are omitted for clarity.

magnetic moment of $3.58 \mu_{\mathrm{B}}$ for a ${ }^{3} \mathrm{H}_{4}$ uranium(IV) ion ${ }^{9,23}$, but well within the range of reported magnetic moments for uranium $(\mathrm{IV})^{24}$. The magnetic moments of $\mathbf{3 M}$ decrease little until $\sim 50 \mathrm{~K}$, then they decrease to magnetic moments spanning $0.86-1.68 \mu_{\mathrm{B}}$ at $2 \mathrm{~K}$. This is not classical uranium(IV) magnetism behaviour, which tends to be a smooth decrease tending to zero with a net low temperature magnetic moment of $\sim 0.5 \mu_{\mathrm{B}}$ due to temperature independent paramagnetism. However, it is characteristic of the magnetic response of uranium(IV) when bound to strong, multiply bonded donors, such as imidos ${ }^{17}$, carbenes $^{25,26}$, phosphidos and arsenidos ${ }^{27,28}$, chalcogenidos ${ }^{29}$, and fluoride ${ }^{30}$, where the magnetic response of the ${ }^{3} \mathrm{H}_{4}$ uranium ion, that is usually dominated by spin orbit coupling effects, is over-ridden by the ligand field ${ }^{31-33}$. In contrast, the data for powdered samples of the $\mathbf{5 M}$, Fig. $4 \mathrm{~b}$, series reveal magnetic moments that span $2.13-2.42 \mu_{\mathrm{B}}$ at $300 \mathrm{~K}$. These data are slightly reduced from the theoretical magnetic moment of $2.54 \mu_{\mathrm{B}}$ for the ${ }^{2} \mathrm{~F}_{5 / 2}$ uranium(V) ion $^{9,23}$, but are in agreement with uranium(V) magnetic moments generally ${ }^{24}$. The magnetic moment data for $5 \mathrm{M}$ change little until $\sim 20 \mathrm{~K}$, at which point they fall sharply to magnetic moments over a narrow range of $1.81-1.97 \mu_{\mathrm{B}}$ at $2 \mathrm{~K}$. This behaviour is typical of classical uranium $(\mathrm{V})$ where this ${ }^{2} \mathrm{~F}_{5 / 2}$ ion is a magnetic doublet at all temperatures, with the low temperature decrease in magnetic moment due to depopulation of low-lying paramagnetic states 9,23 .

The UV/Vis/NIR spectra of $\mathbf{3} \mathbf{L i}, \mathbf{3 C s}, \mathbf{5} \mathbf{L i}$, and $\mathbf{5 C s}$ could be reliably acquired, Fig. 5, however the others could not due to limited solubility once isolated in crystalline form. For all complexes, strong charge transfer bands trail in from the UV region to $\sim 17,000 \mathrm{~cm}^{-1}$. However, for the $3 \mathrm{Li} / \mathrm{Cs}$ complexes multiple and weak $\left(\varepsilon=\leq 60 \mathrm{M}^{-1} \mathrm{~cm}^{-1}\right)$ absorptions are present in the range $3500-17,000 \mathrm{~cm}^{-1}$ that are characteristic of intraconfigurational transitions of uranium(IV $)^{9,23,34}$, whereas the 5Li/Cs series exhibits the fingerprint absorptions for electronic transitions between the $J=5 / 2$ and $7 / 2$ multiplets of the ${ }^{2} \mathrm{~F}$ orbital manifold ${ }^{35}$, where $J$ is the total angular momentum resulting from the interplay of the spin and unquenched orbital angular momenta. Where NMR data could be acquired, the ${ }^{29} \mathrm{Si}$ resonances of $\mathbf{3 L i}, \mathbf{3 C s}, \mathbf{5} \mathbf{L i}$, and $\mathbf{5 C s}$ fall in the expected ranges for uranium(IV) and (V), respectively ${ }^{36}$.

Disproportionation investigation. Complexes $\mathbf{2} \mathbf{M}$ and $\mathbf{3 M}$ are stable indefinitely in toluene or benzene at room temperature or toluene at $80^{\circ} \mathrm{C}$; only in benzene at elevated temperatures do $4 \mathrm{~K}$ / $\mathbf{R b} / \mathbf{C s}$ form. Complexes $\mathbf{4 M}$ are stable in benzene and toluene at room temperature and elevated temperatures (up to $100^{\circ} \mathrm{C}$ ) for days, and the eventual onset of decomposition results in the formation of Tren ${ }^{\text {TIPS }} \mathrm{H}_{3}$ as the major identifiable product, but 1 is not formed. Since $4 \mathbf{K} / \mathbf{R b} / \mathbf{C s}$ can be obtained by heating $2 \mathbf{K}$ / $\mathbf{R b} / \mathbf{C s}$ as well as in situ prepared samples, incomplete metalation of $\mathbf{1}$ and thence its presence in the reaction products can be ruled out. Thus, with the identities of $3 \mathrm{~K} / \mathbf{R b} / \mathbf{C s}-\mathbf{5 K} / \mathbf{R b} / \mathbf{C s}$ confirmed by the structural, spectroscopic, and magnetic characterisation data, the only plausible explanation for the formation of $4 \mathrm{~K} / \mathrm{Rb}$ / Cs from 1 is disproportionation of $2 \mathrm{~K} / \mathrm{Rb} / \mathrm{Cs}$ and formation of the uranium(III)-amide complex [U $\left.{ }^{\mathrm{III}}\left(\mathrm{Tren}^{\mathrm{TIPS}}\right)\left(\mathrm{NH}_{2}\right)\right][\mathrm{M}](\mathbf{6 M}$, $\mathrm{M}=\mathrm{K}, \mathrm{Rb}, \mathrm{Cs}$ ), which is subsequently oxidised to $\mathbf{1}$ by the benzene solvent (see below). In order to probe and confirm this aspect, we examined the disproportionation of crystalline $2 \mathbf{K}$ in 
a

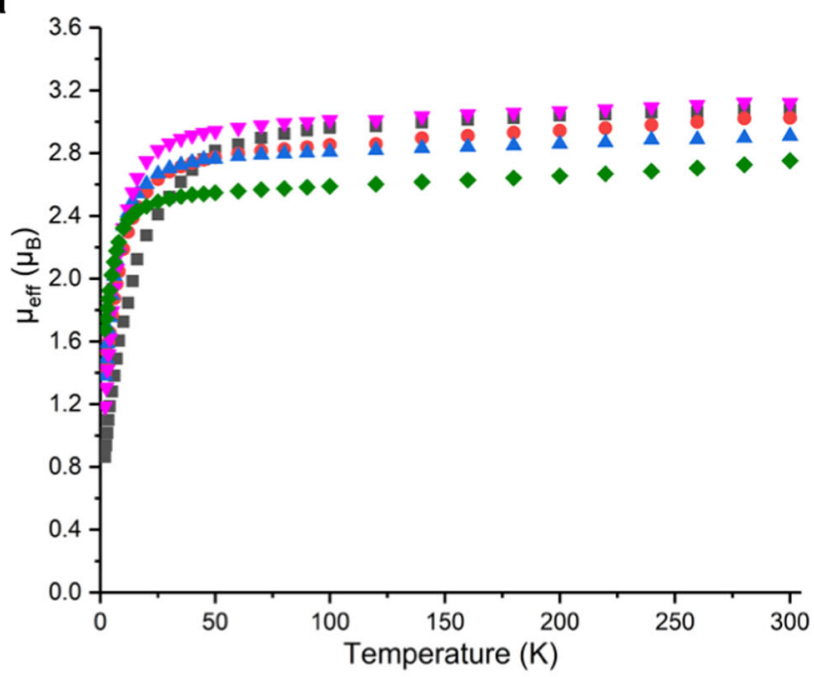

b

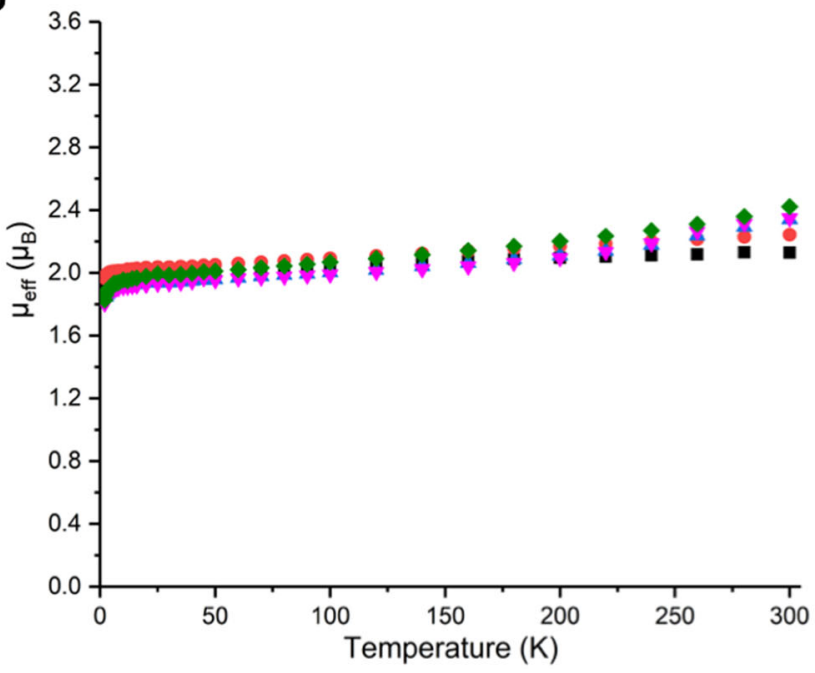

Fig. 4 Variable-temperature effective magnetic moment SQUID data for uranium(IV)-imido (3M) and uranium(V)-nitride (5M) complexes. a $\mu_{\text {eff }}$ $\left(\mu_{B}\right)$ vs $T(K)$ data in a 0.5 T external field for $\mathbf{3} \mathbf{L i}$ (black squares), $\mathbf{3} \mathbf{N a}$ (red circles), 3K (blue triangles), 3Rb (violet triangles), and $\mathbf{3 C}$ s (green squares). $\mathbf{b} \mu_{\text {eff }}\left(\mu_{B}\right)$ vs $T(K)$ data in a 0.5 T external field for $\mathbf{5} \mathbf{L i}$ (black squares), $\mathbf{5} \mathbf{N a}$ (red circles), $\mathbf{5 K}$ (blue triangles), $\mathbf{5} \mathbf{R b}$ (violet triangles), and $\mathbf{5 C s}$ (green squares).

detail. As a pink suspension of pure $2 \mathrm{~K}$ in benzene is warmed the solution turns red as $2 \mathrm{~K}$ dissolves, and after $30 \mathrm{~min}$ at $80^{\circ} \mathrm{C}$ the solution becomes dark red. As the solution cools, dark red crystals of $4 \mathrm{~K}$ grow (30\% yield, 50\% maximum). ${ }^{1} \mathrm{H}$ NMR spectroscopy reveals the presence of $\mathbf{1}$ in the mother liquor (Supplementary Fig. 36), and after work up 1 was isolated in crystalline form $(38 \%$ yield, $50 \%$ maximum). When $\mathbf{2 R \mathbf { b }}$ or $\mathbf{2 C s}$ are used instead of $\mathbf{2 K}$, $\mathbf{4 R b}$ or $\mathbf{4 C s}$ along with $\mathbf{1}$ are similarly isolated. Notably, small quantities of insoluble and distinctly grey precipitates were transiently observed during reactions. The known uranium(III)amide complex $\left[\mathrm{U}^{\mathrm{III}}\left(\mathrm{Tren}^{\mathrm{TIPS}}\right)\left(\mathrm{NH}_{2}\right)\right]\left[\mathrm{K}(\text { benzo-15-crown-5) })_{2}\right]^{37}$ is also distinctively grey and highly insoluble, and, notably, attempts to dissolve it in benzene by warming without exception always results in its oxidation to give solutions exclusively containing $\mathbf{1}$, implying reduction of a sacrificial species. It is germane to note that the grey colour of $\left[\mathrm{U}^{\mathrm{III}}\left(\mathrm{Tren}^{\mathrm{TIPS}}\right)\left(\mathrm{NH}_{2}\right)\right][\mathrm{K}$ (benzo15-crown-5) 2 ] is unique for $\operatorname{Tren}^{\text {TIPS }} \mathrm{U}$ complexes ${ }^{38}$, with all other derivatives being green, yellow, red, light brown, or dark blue/purple and no metal halides, that can often appear to be a

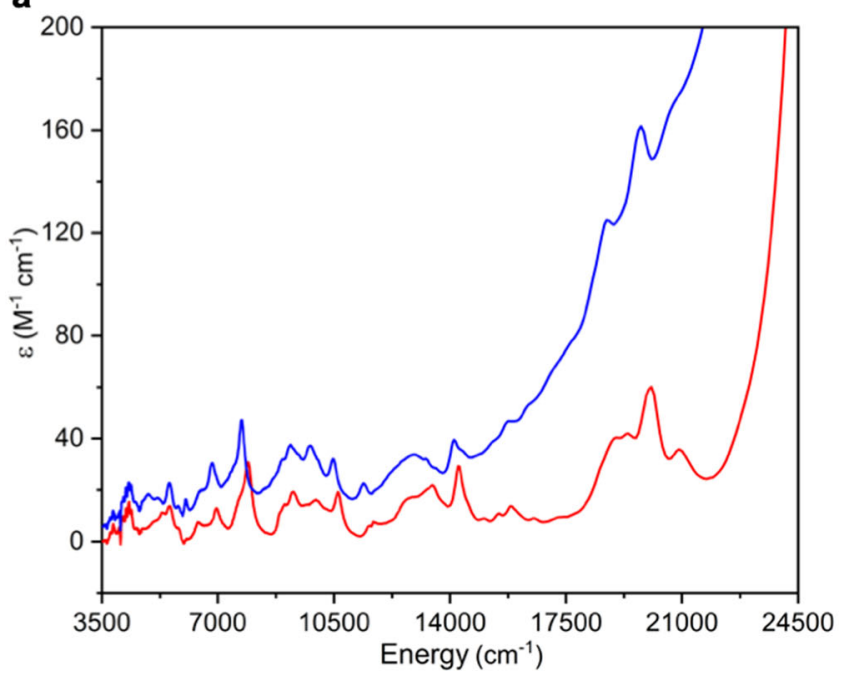

b

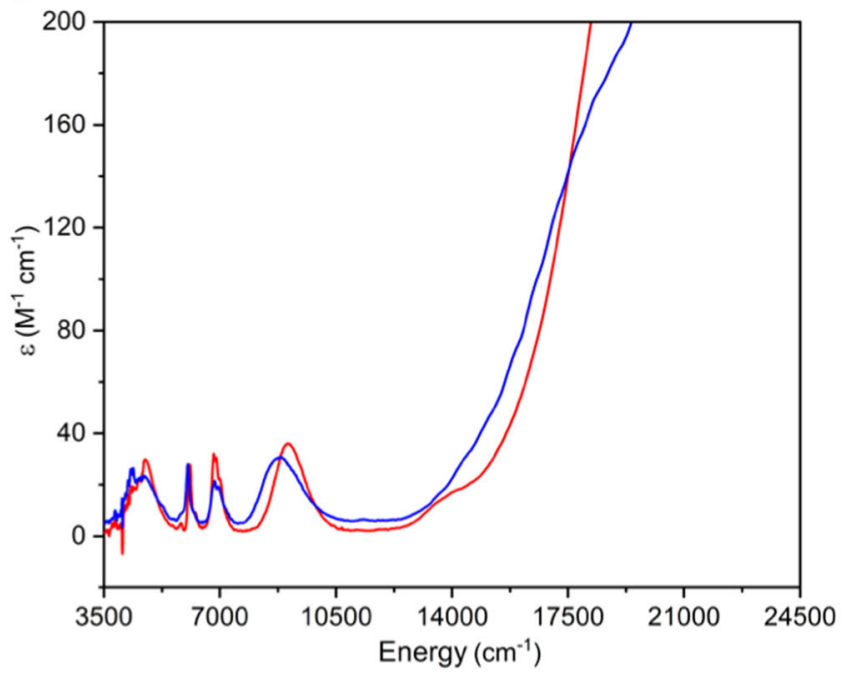

Fig. 5 UV/Vis/NIR spectroscopic data for uranium(IV)-imido (3Li/Cs) and uranium(V)-nitrides (5Li/Cs) complexes. a $\varepsilon\left(\mathrm{M}^{-1} \mathrm{~cm}^{-1}\right)$ vs energy $\left(\mathrm{cm}^{-1}\right)$ of $\mathbf{3} \mathbf{L i}$ (red trace) and $\mathbf{3 C}$ (blue trace) in toluene. $\mathbf{b} \varepsilon\left(\mathrm{M}^{-1} \mathrm{~cm}^{-1}\right)$ vs energy $\left(\mathrm{cm}^{-1}\right)$ of $\mathbf{5} \mathbf{L i}$ (red trace) and $\mathbf{5 C s}$ (blue trace) in toluene.

grey, are present in these reactions. ATR-IR spectra of crude reaction mixtures (Supplementary Fig. 37) are not inconsistent with the formation of $\mathbf{6 K}$ when compared to an authentic pure sample of $\left[\mathrm{U}^{\mathrm{III}}\left(\mathrm{Tren}^{\mathrm{TIPS}}\right)\left(\mathrm{NH}_{2}\right)\right]\left[\mathrm{K} \text { (benzo-15-crown-5) }{ }_{2}\right]^{37}$, but the spectra are not definitive since small variances would be expected, and do manifest, due to the crude-pure comparison. Exhaustive attempts to isolate $\mathbf{6 K}$ from the reaction were unsuccessful, only resulting the isolation of the oxidised product 1. Although reaction concentrations are inherently low, immediately quenching a reaction mixture that produces $4 \mathrm{~K}$ and $6 \mathrm{~K}$ by freezing the benzene solution and recording an X-band (9.44 $\mathrm{GHz}$ ) EPR spectrum reveals a weak signal at $g=2.0023$ (Supplementary Fig. 38), characteristic of the benzene radical anion (linewidth 14 Gauss $)^{39}$. Allowing the reaction to proceed longer then removing the benzene solvent and recording the $\mathrm{X}$-band EPR spectrum on the solid crude product results in a spectrum with the characteristic absorption at $g=3.74$ for $4 \mathrm{~K}$ and also a stronger signal at $g=2.0023$, Fig. 6. Replacing the benzene solvent with toluene completely blocks the production of $4 \mathbf{K}$ by disproportionation, and only $2 \mathbf{K}$ is isolated when toluene is the reaction solvent. These observations suggest that heating mixtures 


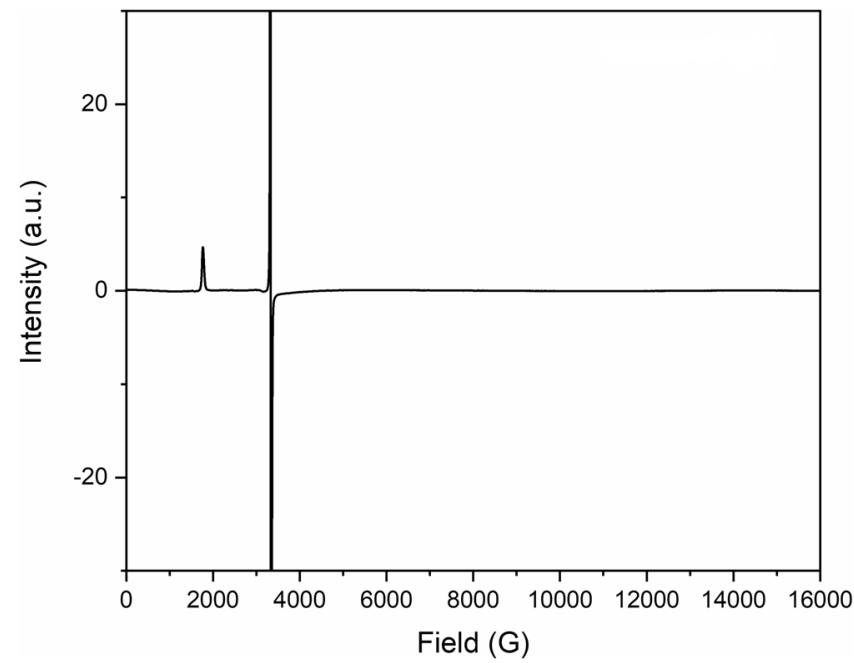

Fig. $6 \mathrm{X}$-band EPR $(9.44 \mathrm{GHz})$ spectrum of solid crude product from the conversion of $2 \mathbf{K}$ to $4 \mathbf{K}$ and $6 \mathbf{K}$. The signal at $g=3.74$ corresponds to $\mathbf{4 K}$ and the one at $g=2.0023$ is characteristic of the benzene radical anion (linewidth 14 Gauss).

of 1 with heavier alkali metal alkyls promotes disproportionation of $2 \mathrm{M}$ to $4 \mathrm{M}$ and $\mathbf{6 M}(\mathrm{M}=\mathrm{K}, \mathrm{Rb}, \mathrm{Cs})$. However, the latter when heated, as necessarily per the experimental conditions, spontaneously converts to $\mathbf{1}$ by reducing the benzene solvent. That this reactivity is not a viable reaction route with toluene is consistent with benzene being easier to reduce than toluene, or viewed from the opposite perspective toluene is more easily oxidised than benzene ${ }^{40}$. The finding that $\mathbf{2 K}, \mathbf{2} \mathbf{R b}$, and $\mathbf{2 C s}$ disproportionate to isolable $4 \mathbf{K}, 4 \mathbf{R b}$, and $4 \mathrm{Cs}$, but $2 \mathrm{Li}$ and $2 \mathrm{Na}$ do not seem to produce $4 \mathrm{Li}$ or $4 \mathrm{Na}$, is consistent with previous EPR spectroscopic observations that potassium, rubidium, and caesium reduce benzene, but lithium and sodium seemingly do not ${ }^{39}$, since the formation of the resulting lithium or sodium benzene radical anion complexes would not be favourable.

Computational reaction profile analysis. In order to further probe and confirm our hypothesis of uranium(IV) disproportionation to uranium(III) and (V), we modelled reaction profiles computationally at the DFT level (B3PW91) including solvent effects (Supplementary Tables 8-47). Firstly, to confirm the validity of our approach $37,41-44$, we modelled the metallation of $\mathbf{1}$ to produce $\mathbf{2 M}$ and $3 \mathrm{M}$, for $\mathrm{M}=\mathrm{Li}, \mathrm{Na}, \mathrm{K}$, Cs, (Supplementary Figs. 39-42) but omitted Rb from these computationally intensive full-structure calculations since it sits in-between $\mathrm{K}$ and Cs. Highlighting the formation of 2Cs and 3Cs as an exemplar (Supplementary Fig. 42), deprotonation of 1 with benzyl caesium proceeds via an adduct that is $3 \mathrm{kcal} / \mathrm{mol}$ lower in energy (Csadduct-in), and negotiation of a low-lying transition state (CsTS-in) that is $3.4 \mathrm{kcal} / \mathrm{mol}$ higher in energy than Cs-adduct-in produces $\left[\mathrm{U}^{\mathrm{IV}}\left(\right.\right.$ Tren $\left.\left.^{\mathrm{TIPS}}\right)(\mu-\mathrm{NH})(\mathrm{Cs})\right]$ (Cs-product-in) that is $14.4 \mathrm{kcal} / \mathrm{mol}$ more stable than the starting point. Dimerisation to give $2 \mathrm{Cs}$ increases the energetic stabilisation to $25.2 \mathrm{kcal} / \mathrm{mol}$ from the starting point, and addition of $\mathrm{Me}_{6}$-Tren finally produces 3Cs lying $27.5 \mathrm{kcal} / \mathrm{mol}$ below the starting point, which is in-line with experimental observations. Adding further reassurance, we note in passing that the final energetic stabilities of $\mathbf{2 M}$ and $\mathbf{3 M}$ are, as expected, ordered $\mathrm{Li}>\mathrm{Na}>\mathrm{K}>\mathrm{Cs}$.

With our reaction profile approach validated, we probed the disproportionation reactions. Again, using the Cs system as a representative example, Fig. 7, starting with 2Cs set to zero, formation of the dinuclear, disproportionated aggregate $\left[\mathrm{UV}^{\mathrm{V}}\right.$ $\left(\right.$ Tren $\left.^{\text {TIPS }}\right)(\mathrm{N})(\mathrm{Cs})_{2}\left(\mathrm{H}_{2} \mathrm{~N}\right)\left(\right.$ Tren $\left.\left.^{\text {TIPS }}\right) \mathrm{U}^{\mathrm{III}}\right]$ (Cs-product-dis), that is $2 \mathrm{kcal} / \mathrm{mol}$ lower in energy than $2 \mathrm{Cs}$, is realised via a transition state (Cs-TS-dis) $27.8 \mathrm{kcal} / \mathrm{mol}$ above the starting point, so this intermediate is kinetically and thermodynamically accessible. Both uranium ions in Cs-TS-dis are still $5 \mathrm{f}^{2}$ uranium(IV) (computed uranium spin densities of 2.23 and 2.18, cf 2.19 for each uranium ion in 2Cs), and this transition state is clearly an inner-sphere hydrogen atom transfer from one imido nitrogen, an incipient nitride, to the other, a nascent amide, as revealed by inspection of the key bond metrics in Cs-TS-dis, Fig. 8. The computed spin densities of the two uranium ions in Cs-productdis are 1.19 and 3.12 , which confirms $5 \mathrm{f}^{1}$ and $5 \mathrm{f}^{3}$ formulations and hence the formation of uranium(V) and (III) ions, respectively. The salient bond distances in Cs-product-dis, Fig. 8, confirms that the nitride and amide linkages are now fully formed, which is reflected in the distinctly asymmetric $\mathrm{Cs}_{2} \mathrm{~N}_{2}$ four-membered ring of this mixed-valent complex, which contrasts to the inversion symmetric $\mathrm{M}_{2} \mathrm{~N}_{2}$ rings of homovalent $\mathbf{2 M}$ and $\mathbf{4 M}$. The energy barrier of $27.8 \mathrm{kcal} / \mathrm{mol}$ is experimentally accessible at $80^{\circ} \mathrm{C}$, accounting for the thermally promoted nature of the disproportionation. Simple dissociation of Csproduct-dis into half an equivalent of $4 \mathrm{Cs}$ and $6 \mathrm{Cs}$ is endothermic by $48.9 \mathrm{kcal} / \mathrm{mol}$ and so is not energetically feasible nor is it experimentally observed. However, addition of benzene and its reduction by [U $\left.\mathrm{U}^{\mathrm{III}}\left(\mathrm{Tren}^{\mathrm{TIPS}}\right)\left(\mathrm{NH}_{2}\right)\right][\mathrm{Cs}]$ to give $\mathbf{4 M}, \mathbf{1}$, and the caesium salt of the benzene radical anion is energetically favourable, at $12.0 \mathrm{kcal} / \mathrm{mol}$ below the Cs-product-dis, and the formation of the benzene radical anion is experimentally observed by our EPR studies on the in-situ solution of the reaction. Further, addition of $\mathrm{Me}_{6}$-Tren is even more energetically stabilising by a further $4.4 \mathrm{kcal} / \mathrm{mol}$. When benzene solvent is replaced by toluene, the production of $4 \mathrm{M}, 1$, and the caesium salt of the toluene radical anion is now disfavoured, being $14.2 \mathrm{kcal} /$ mol above Cs-product-dis, which can be related to the fact that benzene is far easier to reduce than toluene; whilst this route is in principle accessible, it is ultimately an endothermic product and so does not occur.

To assess whether the experimental observations are independently reproduced computationally, we examined the conversion of $2 \mathbf{M}$ to $\mathbf{4 M}+\mathbf{1}+\mathbf{M}$ (arene) for $\mathrm{Li}, \mathrm{Na}$, and $\mathrm{K}$, again omitting $\mathrm{Rb}$ since it sits in-between $\mathrm{K}$ and $\mathrm{Cs}$ which both give the same product outcome. We find that, with some variations of exact enthalpies, essentially the same reaction profile and outcome is computed for K (Supplementary Fig. 43) as for Cs, consistent with experiment; $\mathrm{Rb}$ would then evidently give the same outcome, as experimentally observed. However, when the corresponding $\mathrm{Li}$ and $\mathrm{Na}$ profiles are computed, Fig. 9 and Supplementary Information Fig. 44, we find that whilst the final, hypothetical products $\mathbf{5 L i} / \mathbf{N a}$ reside at slightly lower energies than the starting points $(-0.4$ and $-2.9 \mathrm{kcal} / \mathrm{mol})$, the preceding $4 \mathrm{Li} / 4 \mathrm{Na}+\mathbf{1}+\mathbf{M}$ (arene) products are slightly positive with respect to the starting points $(1.3$ and $0.9 \mathrm{kcal} / \mathrm{mol})$. As expected, for $\mathrm{Li}$ and $\mathrm{Na}$, spontaneous cleavage of $\mathbf{M}$-product-dis for $\mathrm{Li}$ and $\mathrm{Na}$ are both very unfavourable ( $>40 \mathrm{kcal} / \mathrm{mol})$, underscoring the importance of the solvent in these reactions, and the toluene routes are also very unfavourable ( $>24 \mathrm{kcal} / \mathrm{mol}$ ) compared to the starting points. All those reaction outcomes are therefore thermodynamically endothermic overall and so do not occur. Importantly, the Li-product-dis and Na-product-dis compounds are endothermic products compared to their respective starting points (13.3 and $4.5 \mathrm{kcal} / \mathrm{mol}$ ) and the energy barriers are now $>31 \mathrm{kcal} / \mathrm{mol}$ (cf the $\mathrm{K}$ and $\mathrm{Cs}$ congeners are $<28 \mathrm{kcal} / \mathrm{mol}$ ) so these intermediates are kinetically and thermodynamically disfavoured.

The reaction profile calculations thus independently reproduce and verify the experimental hypothesis, confirming that disproportionation of uranium(IV) to uranium(III) and (V) has occurred, and that the solvent blocks or facilitates the reactivity, 


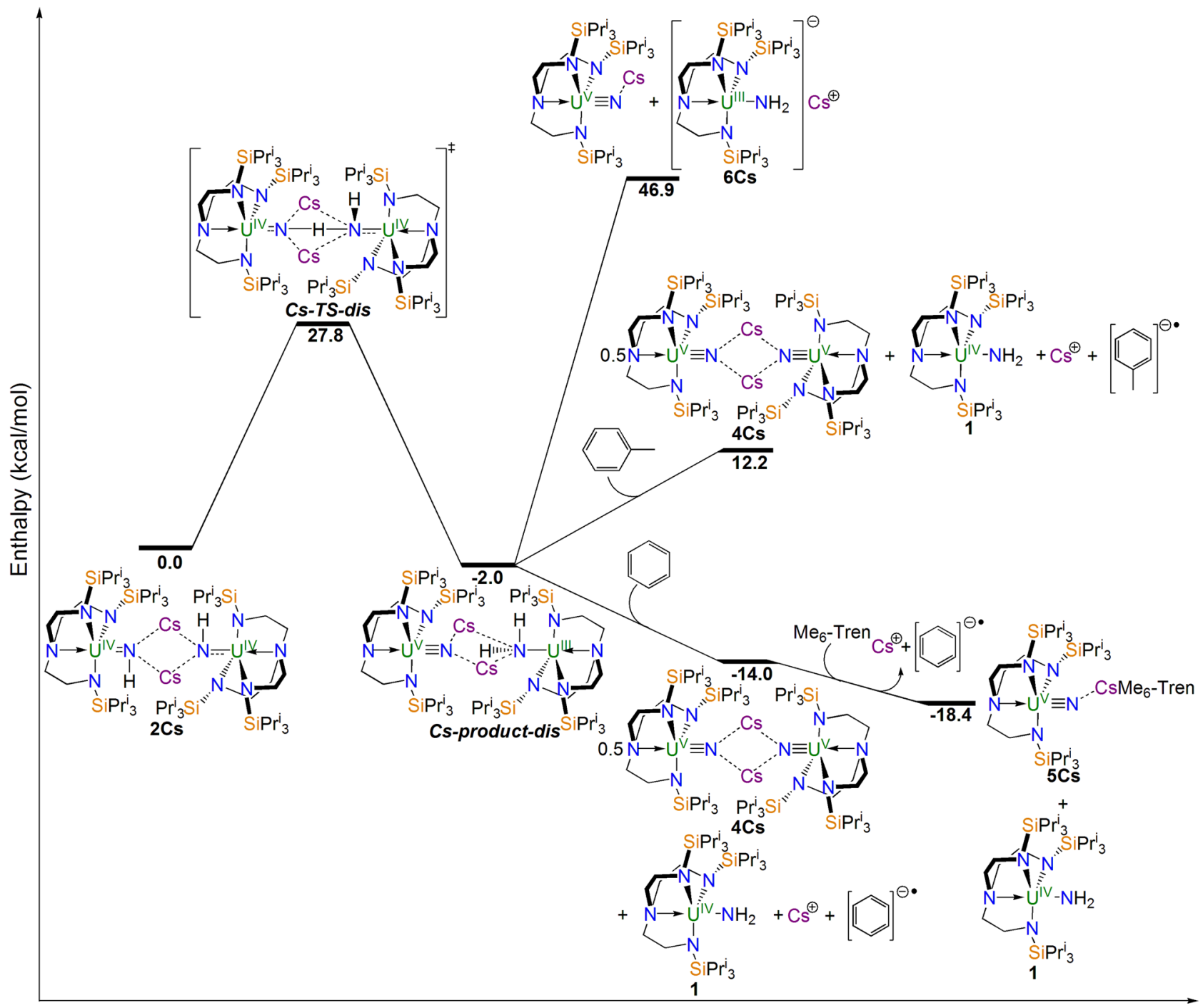

Reaction coordinate

Fig. 7 Computed reaction profile for the disproportionation of $\mathbf{2 C s}$ to $\mathbf{4 C s} / \mathbf{1} / \mathbf{C s}^{+}\left(\mathbf{C}_{\mathbf{6}} \mathbf{H}_{\mathbf{6}}\right)^{-\bullet}$. Complex $\mathbf{2 C s}$ containing two uranium(IV) ions reacts via transition state $\mathbf{C s - T S - d i s ~ t o ~ g i v e ~ t h e ~ d i s p r o p o r t i o n a t i o n ~ i n t e r m e d i a t e ~} \mathbf{C s - p r o d u c t - d i s ~ w h e r e ~ u r a n i u m ( V ) ~ a n d ~ ( I I I ) ~ i o n s ~ a r e ~ f o r m e d . ~ S p o n t a n e o u s ~ c l e a v a g e ~}$ of Cs-product-dis to two monomer units is clearly disfavoured, as is reaction with toluene to give $\mathbf{4 C s}, \mathbf{1}$, and the caesium toluene radical anion salt. Cs-product-dis however does react with benzene to give $\mathbf{4 C s}, \mathbf{1}$, and the caesium benzene radical anion salt. Complex $\mathbf{4 C s}$ is then converted to $\mathbf{5 C s}$ using the capping agent $\mathrm{Me}_{6}$-Tren.

in the latter case also accounting for the oxidation of the uranium (III) component to uranium(IV). The regeneration of $\mathbf{1}$ from this disproportionation reaction proposed computationally also nicely independently corroborates the experimental observation that addition of an increased excess of potassium alkyl to $\mathbf{1}$ produces increased yields of $\mathbf{4 K}$, because for each disproportionation event, the uranium(III) component is oxidised to $\mathbf{1}$ which under the action of further deprotonating agent in a thermolytic regime disproportionates again, generating more $\mathbf{4 K}$.

\section{Discussion}

The reactivity disclosed here provides a complementary example of uranium(IV) disproportionation to the other example in the literature ${ }^{14}$. The prior report involved a diuranium(IV)-nitride complex disproportionating under the action of methyltriflate to a uranium(III)-triflate and uranium(V)-imido mixture ${ }^{14}$, whereas here we report a diuranium(IV)-imido disproportionating to uranium(V)-nitride and uranium(III)-amide under the action of solvent and temperature. Nitrides are typically regarded as being difficult linkages to access in the coordination sphere of actinides, so a reaction that produces a nitride, rather than a nitride reacting to give something else, is unusual. The results reported here now shed light on the factors that can induce uranium(IV) to disproportionate in as much as clearly the ligands play a key role, but the experimental and computational results both also point to the decisive role that the solvent plays in facilitating, or not, the uranium(IV) disproportionation. This constitutes an unusual level of modification of a fundamental thermodynamic property of uranium to promote a redox reaction, rather than just effecting kinetic control or blocking, in three examples by a common ligand class (imido) and widely used solvent (benzene) in combination. These external factors have shifted a fundamental redox phenomenon from unfavourable to favourable under relatively mild conditions, demonstrating a dependence on external drivers that is more reminiscent of transition metal chemistry rather than lanthanide and actinide chemistry. The establishment of two types of conceptually opposite (nitride to imido and imido to 


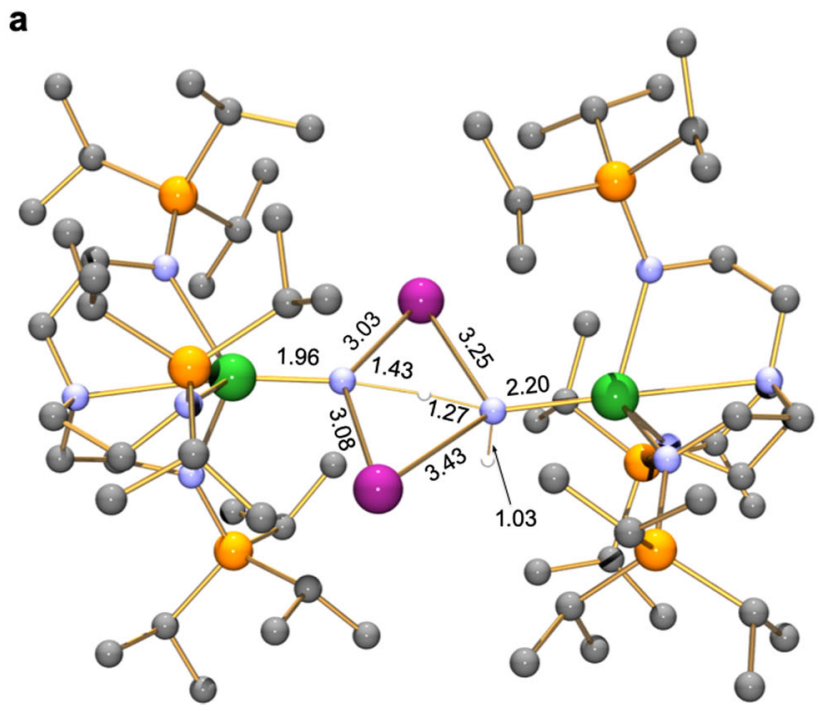

b

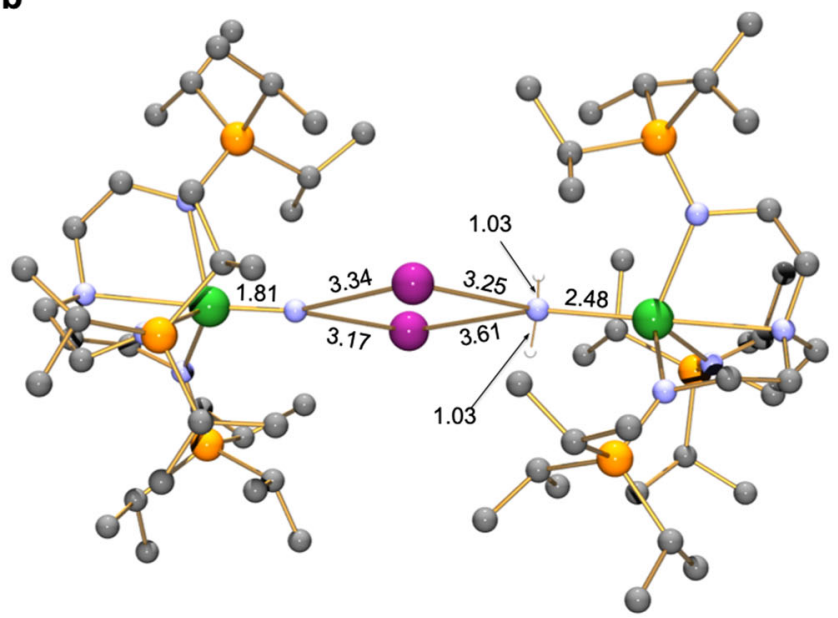

Fig. 8 Computed structures, with C-H hydrogen atoms omitted for clarity, of the key transition state and intermediate in the disproportionation of $\mathbf{2 C s}$ to $\mathbf{4 C s} / \mathbf{1} / \mathbf{C s}^{+}\left(\mathbf{C}_{\mathbf{6}} \mathbf{H}_{\mathbf{6}}\right)^{-\bullet}$. a The structure of Cs-TS-dis with key bond distances $(\AA)$. $\mathbf{b}$ The structure of Cs-product-dis with key bond distances $(\AA)$. Key: uranium, green; caesium, purple; carbon, grey; hydrogen, white; nitrogen, blue; silicon, orange.

nitride) uranium(IV) disproportionation suggests the potential for elaboration, and indeed it may be a more widespread reaction pathway under more extreme conditions than is currently recognised, for example in highly radiolytic scenarios. For example, the inner-sphere proton migration during the uranium (IV) disproportionation reported here is reminiscent of protonpromoted disproportionation of di-actinyl(V) cation-cation complexes $^{45-50}$ that drives actinide ion mobility and complex, problematic equilibria in nuclear fuel extraction processes, e.g. PUREX $^{16}$, and bio-mediated deposition of uranium(IV)-oxides from uranyl(VI) in the environment ${ }^{10,11}$. Tellingly, the disproportionation of uranium(IV) reported here involves $\mathrm{H}_{2} \mathrm{~N}^{-}$, $\mathrm{HN}^{2-}$, and $\mathrm{N}^{3-}$ ligands, which parallels the prevalence of isoelectronic and isolobal $\mathrm{H}_{2} \mathrm{O}, \mathrm{HO}^{-}$, and $\mathrm{O}^{2-}$ ligands in the disproportionation chemistry of $\operatorname{uranium}(\mathrm{V})$ in cation-cation complexes $^{16,45}$, so it would seem that the softer nitrogen-based ligands facilitate disproportionation with the lower oxidation state of uranium and analogously the harder oxygen-based ligands with the higher oxidation state of uranium. There are many uranium(V)-oxo complexes, including uranyl(V), and so $\mathrm{H}^{+}$-promoted disproportion of $\mathrm{UV}^{\mathrm{V}}=\mathrm{O}$ linkages is well- precedented. However, there are few $\mathrm{U}^{\mathrm{IV}}=\mathrm{NH}$ linkages ${ }^{17,51}$, and so disproportionation of $\mathrm{U}^{\mathrm{IV}}=\mathrm{NH}$ linkages could in principle be expanded with other ancillary ligands to Tren ${ }^{\text {TIPS }}$. Thus, the development of the third redox disproportionation reaction for uranium hints at the potential to have implications for the chemistry of uranium in a range of scientific, technological, radiochemical, and environmental scenarios.

\section{Methods}

General. All manipulations were carried out under an inert atmosphere of dry nitrogen using Schlenk techniques, or an MBraun UniLab glovebox operating under an atmosphere of dry nitrogen. THF, toluene and pentane solvents were dried by passage through activated alumina towers and degassed before use. Hexanes and benzene were distilled from potassium. All solvents were stored over potassium mirrors except for ethers which were stored over activated $4 \AA$ sieves. Deuterated solvents were distilled from potassium, degassed by three freeze-pumpthaw cycles and stored under nitrogen prior to use. $\mathrm{Bu} \mathrm{t}^{\mathrm{L}} \mathrm{i}(1.0 \mathrm{M}$ in pentane), and $\mathrm{N}$ $\left(\mathrm{CH}_{2} \mathrm{CH}_{2} \mathrm{NMe}_{2}\right)_{3}$ were used as purchased. $\mathrm{MCH}_{2} \mathrm{Ph}(\mathrm{M}=\mathrm{Na}, \mathrm{K}, \mathrm{Rb}, \mathrm{Cs}),[\mathrm{U}$ $\left(\right.$ Tren $\left.\left.^{\text {TIPS }}\right)\left(\mathrm{NH}_{2}\right)\right](\mathbf{1})$, [\{U(Tren $\left.\left.\left.{ }^{\text {TIPS }}\right)(\mu-\mathrm{NH})(\mu-\mathrm{M})\right\}_{2}\right](\mathbf{2 M}, \mathrm{M}=\mathrm{Li}, \mathrm{Na}, \mathrm{K}, \mathrm{Rb}, \mathrm{Cs})$, and $\left[\left\{\mathrm{U}\left(\text { Tren }^{\mathrm{TIPS}}\right)(\mu-\mathrm{N})(\mu-\mathrm{M})\right\}_{2}\right](\mathbf{4 M}, \mathrm{M}=\mathrm{Li}, \mathrm{Na}, \mathrm{K}, \mathrm{Rb}, \mathrm{Cs})$ were prepared using literature methods $17-21,52$.

Single crystals were examined variously on either (a) an Oxford Diffraction SuperNova Atlas CCD diffractometer using mirror-monochromated MoKa radiation $(\lambda=0.71073 \AA$ ), (b) a Rigaku Xcalibur2 diffractometer equipped with an Atlas CCD area detector and a sealed tube source with graphite-monochromated MoKa radiation $(\lambda=0.71073 \AA$ ) , or (c) a Rigaku FR-X diffractometer equipped with a Hypix $6 \mathrm{HE}$ photon counting pixel array detector with mirrormonochromated MoKa $(\lambda=0.71073 \AA)$ or CuKa $(\lambda=1.5418 \AA)$ radiation. Intensities were integrated from a sphere of data recorded on narrow $\left(1.0^{\circ}\right)$ frames by $\omega$ rotation. Cell parameters were refined from the observed positions of all strong reflections in each data set. Gaussian grid face-indexed absorption corrections with a beam profile correction were applied. The structures were solved either by dual methods using SHELXT ${ }^{53}$ and all non-hydrogen atoms were refined by full-matrix least-squares on all unique $F^{2}$ values with anisotropic displacement parameters with exceptions noted in the respective cif files. Hydrogen atoms were refined with constrained geometries and riding thermal parameters; $U_{\text {iso }}(\mathrm{H})$ was set at 1.2 (1.5 for methyl groups) times $U_{\text {eq }}$ of the parent atom. The largest features in final difference syntheses were close to heavy atoms and were of no chemical significance. CrysAlisPro was used for control and integration ${ }^{54}$, and SHELXL and Olex2 were employed for structure refinement ${ }^{55,56}$. ORTEP-3 and POV-Ray were employed for molecular graphics ${ }^{57,58} .{ }^{1} \mathrm{H},{ }^{29} \mathrm{Si}\left\{{ }^{1} \mathrm{H}\right\}$, and ${ }^{7} \mathrm{Li}\left\{{ }^{1} \mathrm{H}\right\} \mathrm{NMR}$ spectra were recorded on a Bruker 400 spectrometer operating at $400,79,155 \mathrm{MHz}$, respectively; chemical shifts are quoted in ppm and are relative to TMS $\left({ }^{1} \mathrm{H},{ }^{29} \mathrm{Si}\right)$ and $\mathrm{LiCl}\left({ }^{7} \mathrm{Li}\right)$. ATR-IR spectra were recorded on a Bruker Alpha spectrometer with a PlatinumATR module in the glovebox. UV-Vis-NIR spectra were recorded on a Perkin Elmer $\mathrm{LMD}^{\mathrm{TM}} 750$ spectrometer. Data were collected in a $1 \mathrm{~mm}$ path-length cuvette loaded in an MBraun glovebox and were run versus the appropriate solvent. EPR spectra were measured using a X-band $(9.44 \mathrm{GHz})$ Bruker Elexsys E500 spectrometer equipped with an ER4118SMS5 resonator at $5 \mathrm{~K}$. Solution samples were transferred to the quartz tubes under argon, and the tubes were flame sealed prior to experiments. Field corrections were applied to the raw data using Bruker strong pitch $(g=2.0026)$ as a reference. Static variable-temperature magnetic moment data were recorded in an applied dc field of $0.5 \mathrm{~T}$ on by Quantum Design MPMS XL7 or MPMS 3 (for 3Li and 5Na) SQUID magnetometers using recrystallised powdered samples. Care was taken to ensure complete thermalisation of the sample before each data point was measured and samples were immobilised in an eicosane matrix to prevent sample reorientation during measurements. Diamagnetic corrections were applied for using tabulated Pascal constants and measurements were corrected for the effect of the blank sample holders (flame sealed Wilmad NMR tube and straw) and eicosane matrix. CHN microanalyses were carried out by Martin Jennings and Anne Davies at the University of Manchester.

Preparation of [U(Tren $\left.{ }^{\text {TIPS }}\right)(\boldsymbol{\mu}-\mathbf{N H})(\boldsymbol{\mu}-\mathrm{Li})\left(\mathbf{M e}_{6}-\right.$ Tren $\left.)\right]$ (3Li). Method A: A solution of $\mathrm{Me}_{6}$-Tren $(0.17 \mathrm{~g}, 0.75 \mathrm{mmol})$ in hexanes $(5 \mathrm{ml})$ was added slowly to a pre-cooled $\left(-78^{\circ} \mathrm{C}\right)$ solution of $\mathrm{Bu} t \mathrm{Li}(0.035 \mathrm{~g}, 0.55 \mathrm{mmol})$ in hexanes $(10 \mathrm{ml})$. After $10 \mathrm{~min}$, a solution of $1(0.43 \mathrm{~g}, 0.50 \mathrm{mmol})$ in hexanes $(10 \mathrm{ml})$ was added at $-78^{\circ} \mathrm{C}$. The mixture was allowed to warm to room temperature and stirred for further $16 \mathrm{~h}$, forming a red solution. All the volatiles were removed in vacuo to afford a pink solid, which was extracted in pentane $(5 \mathrm{ml})$ and filtered. Pink crystals of $3 \mathrm{Li}$ were obtained by storing the resulting red solution at $-30^{\circ} \mathrm{C}$ for 2 days. Yield: $0.21 \mathrm{~g}, 38 \%$. Method B: $\mathrm{Me}_{6}$-Tren $(0.17 \mathrm{~g}, 0.75 \mathrm{mmol})$ was added to a pale pink suspension of $2 \mathrm{Li}(0.44 \mathrm{~g}, 0.25 \mathrm{mmol})$ in toluene $(20 \mathrm{ml})$ and the reaction was stirred for $24 \mathrm{~h}$ at room temperature. Volatiles were removed from the resulting red solution in vacuo. The resulting solid was extracted into pentane $(5 \mathrm{ml})$ and filtered; the red filtrate was stored at $-30{ }^{\circ} \mathrm{C}$ for $16 \mathrm{~h}$ to yield pink crystals of $3 \mathrm{Li}$ which were isolated by decanting the mother liquor and dried in vacuo. Yield: 0.36 g, $65 \%$. Anal. Calcd for $\mathrm{C}_{45} \mathrm{H}_{106} \mathrm{LiN}_{9} \mathrm{Si}_{3} \mathrm{U}$ : C, 49.02; H, 9.69; N, 11.43\%. Found: C, 


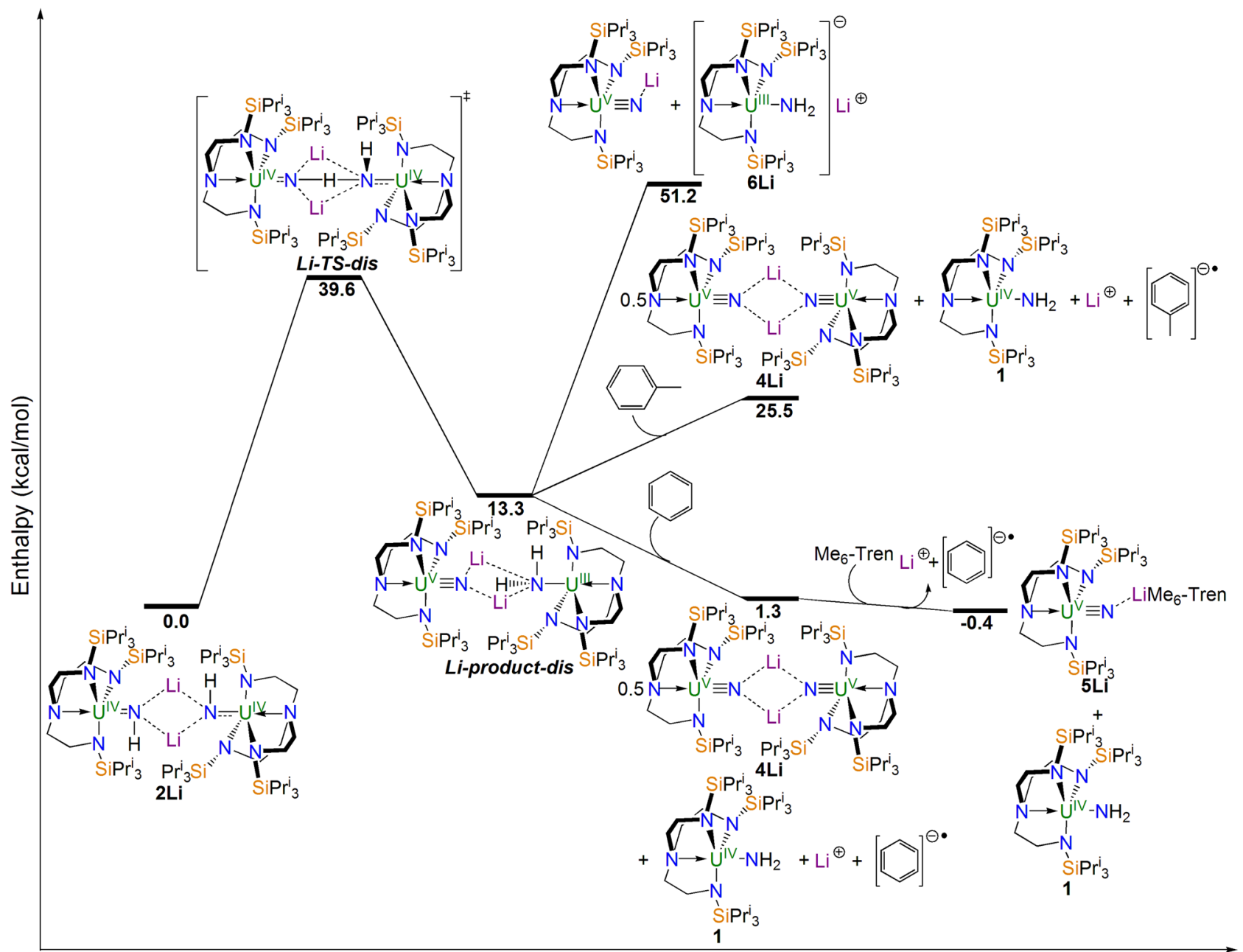

\section{Reaction coordinate}

Fig. 9 Computed reaction profile for the hypothetical disproportionation of $\mathbf{2} \mathbf{L i}$ to $\mathbf{4} \mathbf{L i} / \mathbf{1} / \mathbf{L i} \mathbf{L}^{+}\left(\mathbf{C}_{\mathbf{6}} \mathbf{H}_{\mathbf{6}}\right)^{-} \cdot \boldsymbol{\bullet}$. Complex $\mathbf{2} \mathbf{L i}$ containing two uranium(IV) ions reacts via transition state $\mathbf{L i}$-TS-dis to give the disproportionation intermediate $\mathbf{L i}$-product-dis where uranium(V) and (III) ions are formed, but this is an endothermic reaction. Spontaneous cleavage of Li-product-dis to two monomer units is clearly disfavoured, as is reaction with toluene to give $\mathbf{4 L i}$, $\mathbf{1}$, and the lithium toluene radical anion salt. If $\mathbf{L i}$-product-dis formed it would, however, react with benzene to give $\mathbf{4} \mathbf{L i}$, $\mathbf{1}$, and the lithium toluene radical anion salt. Complex $\mathbf{4} \mathbf{L i}$ would then converted to $\mathbf{5} \mathbf{L i}$ using the capping agent $\mathrm{Me}_{6}$-Tren.

48.77; H, 9.99; N, $11.37 \% .{ }^{1} \mathrm{H}$ NMR $\left(400 \mathrm{MHz}, \mathrm{C}_{6} \mathrm{D}_{6}, 298 \mathrm{~K}\right): \delta-24.03(\mathrm{br}, 54 \mathrm{H}$ $\left.\mathrm{CH}\left(\mathrm{CH}_{3}\right)_{2}\right),-23.72\left(\mathrm{br}, 9 \mathrm{H}, \mathrm{CH}\left(\mathrm{CH}_{3}\right)_{2}\right), 13.71\left(\mathrm{br}, 6 \mathrm{H}, \mathrm{NCH}_{2} \mathrm{CH}_{2}\right), 18.39(\mathrm{br}$, $\left.18 \mathrm{H}, \mathrm{N}\left(\mathrm{CH}_{3}\right)_{2}\right), 25.04$ (br, $\left.6 \mathrm{H}, \mathrm{CH}_{2}-\mathrm{Me}_{6}-\mathrm{TREN}\right), 37.50$ (br, 6H, $\mathrm{CH}_{2}-\mathrm{Me}_{6}-\mathrm{TREN}$ ), 105.44 (br, $6 \mathrm{H}, \mathrm{NCH}_{2} \mathrm{CH}_{2}$ ). The $\mathrm{NH}$ resonance was not observed in the ${ }^{1} \mathrm{H}$ NMR spectrum. ${ }^{7} \mathrm{Li}\left\{{ }^{1} \mathrm{H}\right\}$ NMR $\left(155 \mathrm{MHz}, 298 \mathrm{~K}, \mathrm{C}_{6} \mathrm{D}_{6}\right): \delta 2.03(\mathrm{br}) .{ }^{29} \mathrm{Si}\left\{{ }^{1} \mathrm{H}\right\}$ NMR $(79$ $\mathrm{MHz}, \mathrm{C}_{6} \mathrm{D}_{6}, 298 \mathrm{~K}$ ): $\delta-155.20(\mathrm{br})$. ATR-IR $v / \mathrm{cm}^{-1}: 2935$ (br, w), 2857 (m), 2823 $(\mathrm{w}), 1457(\mathrm{~m}), 1355(\mathrm{w}), 1273(\mathrm{w}), 1115(\mathrm{w}), 1061(\mathrm{~m}), 1012(\mathrm{w}), 931(\mathrm{~s}), 881(\mathrm{~s})$, 733 (vs), $670(\mathrm{~s}), 624(\mathrm{~m}), 561(\mathrm{w}), 510(\mathrm{w}), 441(\mathrm{w})$. The NH stretching absorption was not observed. $\mu_{\text {eff }}$ (Evan's method, $\mathrm{C}_{6} \mathrm{D}_{6}, 298 \mathrm{~K}$ ): $2.3 \mu_{\mathrm{B}}$.

Preparation of $\left[\mathrm{U}\left(\mathrm{Tren}^{\mathrm{TIPS}}\right)(\mu-\mathrm{NH})(\mu-\mathrm{Na})\left(\mathrm{Me}_{6}-\mathrm{Tren}\right)\right](3 \mathrm{Na})$. Method A: A solution of $\mathrm{Me}_{6}$-Tren $(0.17 \mathrm{~g}, 0.75 \mathrm{mmol})$ in toluene $(5 \mathrm{ml})$ was added slowly to a pre-cooled $\left(-78^{\circ} \mathrm{C}\right)$ mixture of $\mathrm{NaCH}_{2} \mathrm{Ph}(0.063 \mathrm{~g}, 0.55 \mathrm{mmol})$ in toluene $(10 \mathrm{ml})$. After $30 \mathrm{~min}$, a solution of $1(0.43 \mathrm{~g}, 0.50 \mathrm{mmol})$ in toluene $(10 \mathrm{ml})$ was added at $-78^{\circ} \mathrm{C}$. The mixture was allowed to warm to room temperature and stirred for further $16 \mathrm{~h}$, forming a red solution. The reaction was filtered and concentrated to $5 \mathrm{ml}$. Pink crystals of $3 \mathrm{Na}$ were obtained by storing the resulting red solution at $-30^{\circ} \mathrm{C}$ for a few days. Yield: $0.26 \mathrm{~g}, 47 \%$. Method B: $\mathrm{Me}_{6}$-Tren $(0.17 \mathrm{~g}, 0.75 \mathrm{mmol})$ was added to a pink suspension of $2 \mathrm{Na}(0.45 \mathrm{~g}, 0.25 \mathrm{mmol})$ in toluene $(20 \mathrm{ml})$ and the reaction was stirred for $24 \mathrm{~h}$ at room temperature. Volatiles were removed from the resulting red solution in vacuo. The resulting solid was washed with pentane $(2 \times 5 \mathrm{ml})$ and dried in vacuo, giving $3 \mathrm{Na}$ as a pink solid. Yield: $0.42 \mathrm{~g}, 76 \%$. Anal. Calcd for $\mathrm{C}_{45} \mathrm{H}_{106} \mathrm{NaN}_{9} \mathrm{Si}_{3} \mathrm{U}$ : C, 48.32; H, 9.55; N, 11.27\%. Found: C, 48.04; H, 9.67; $\mathrm{N}, 10.86 \% .{ }^{1} \mathrm{H}$ NMR $\left(400 \mathrm{MHz}, \mathrm{C}_{6} \mathrm{D}_{6}, 298 \mathrm{~K}\right): \delta-24.88\left(\mathrm{br}, 54 \mathrm{H}, \mathrm{CH}\left(\mathrm{CH}_{3}\right)_{2}\right)$, -22.56 (br, 9H, CH( $\left.\left(\mathrm{CH}_{3}\right)_{2}\right), 14.42\left(\mathrm{br}, 6 \mathrm{H}, \mathrm{NCH}_{2} \mathrm{CH}_{2}\right), 22.29-24.13(\mathrm{br}, 30 \mathrm{H}$, $\left.\mathrm{CH}_{2} \mathrm{CH}_{2} \mathrm{~N}\left(\mathrm{CH}_{3}\right)_{2}\right), 107.21\left(\mathrm{br}, 6 \mathrm{H}, \mathrm{NCH}_{2} \mathrm{CH}_{2}\right)$. The $\mathrm{NH}$ resonance was not observed in the ${ }^{1} \mathrm{H}$ NMR spectrum. Reliable ${ }^{29} \mathrm{Si}$ NMR and UV/Vis/NIR spectra and solution magnetic moment (Evan's method) could not be obtained, due to $3 \mathrm{Na}$ being only partially soluble in aromatic solvent (benzene and toluene) once isolated, and it decomposes in polar solvents. ATR-IR $v / \mathrm{cm}^{-1}: 2936(\mathrm{br}, \mathrm{w}), 2858(\mathrm{~m})$, $2825(\mathrm{w}), 1461(\mathrm{~m}), 1357(\mathrm{w}), 1273(\mathrm{w}), 1116(\mathrm{w}), 1063(\mathrm{~m}), 1010(\mathrm{w}), 934(\mathrm{~s}), 880$ $(\mathrm{s}), 735(\mathrm{vs}), 671(\mathrm{~s}), 624(\mathrm{~m}), 561(\mathrm{w}), 509(\mathrm{w}), 440(\mathrm{w})$. The NH stretching absorption was not observed.

Preparation of $\left[\mathrm{U}\left(\mathrm{Tren}^{\mathrm{TIPS}}\right)(\boldsymbol{\mu}-\mathrm{NH})(\mu-\mathrm{K})\left(\mathrm{Me}_{\mathbf{6}}-\mathrm{Tren}\right)\right]$ (3K). Method A: A solution of $\mathrm{Me}_{6}$-Tren $(0.17 \mathrm{~g}, 0.75 \mathrm{mmol})$ in toluene $(5 \mathrm{ml})$ was added slowly to a precooled $\left(-78^{\circ} \mathrm{C}\right)$ mixture of $\mathrm{KCH}_{2} \mathrm{Ph}(0.072 \mathrm{~g}, 0.55 \mathrm{mmol})$ in toluene $(10 \mathrm{ml})$. After $30 \mathrm{~min}$, a solution of $\mathbf{1}(0.43 \mathrm{~g}, 0.50 \mathrm{mmol})$ in toluene $(10 \mathrm{ml})$ was added at $-78^{\circ} \mathrm{C}$. The mixture was allowed to warm to room temperature and stirred for further $16 \mathrm{~h}$, forming a red solution. The mixture was filtered and concentrated to $5 \mathrm{ml}$. Pink crystals of $3 \mathrm{~K}$ were obtained by storing the resulting red solution at $-30^{\circ} \mathrm{C}$ for 2 days. Yield: $0.25 \mathrm{~g}, 43 \%$. Method B: $\mathrm{Me}_{6}$-Tren $(0.17 \mathrm{~g}, 0.75 \mathrm{mmol})$ was added to a pink suspension of $2 \mathrm{~K}(0.45 \mathrm{~g}, 0.25 \mathrm{mmol})$ in toluene $(20 \mathrm{ml})$ and the reaction was stirred for $24 \mathrm{~h}$ at room temperature. Volatiles were removed from the resulting red solution in vacuo. The product was washed with pentane $(2 \times 5 \mathrm{ml})$ and dried in vacuo, giving $3 \mathrm{~K}$ as a pink solid. Yield: $0.36 \mathrm{~g}, 63 \%$. Anal. Calcd for $\mathrm{C}_{45} \mathrm{H}_{106} \mathrm{KN}_{9} \mathrm{Si}_{3} \mathrm{U}: \mathrm{C}, 47.63 ; \mathrm{H}$, 9.42; N, 11.11\%. Found: C, 47.52; H, 9.54; N, 10.65\%. ${ }^{1} \mathrm{H}$ NMR $\left(400 \mathrm{MHz}, \mathrm{C}_{6} \mathrm{D}_{6}, 298\right.$ $\mathrm{K}): \delta-23.74\left(\mathrm{br}, 54 \mathrm{H}, \mathrm{CH}\left(\mathrm{CH}_{3}\right)_{2}\right),-20.52\left(\mathrm{br}, 9 \mathrm{H}, \mathrm{CH}\left(\mathrm{CH}_{3}\right)_{2}\right), 15.78(\mathrm{br}, 6 \mathrm{H}$, $\left.\mathrm{NCH}_{2} \mathrm{CH}_{2}\right), 22.42\left(\mathrm{br}, 30 \mathrm{H}, \mathrm{CH}_{2} \mathrm{CH}_{2} \mathrm{~N}\left(\mathrm{CH}_{3}\right)_{2}\right), 106.55\left(\mathrm{br}, 6 \mathrm{H}, \mathrm{NCH}_{2} \mathrm{CH}_{2}\right)$. The NH resonance was not observed in the ${ }^{1} \mathrm{H}$ NMR spectrum. Reliable ${ }^{29} \mathrm{Si} \mathrm{NMR}$ and UV/ Vis/NIR spectra and solution magnetic moment (Evan's method) could not be obtained, due to $3 \mathbf{K}$ being only partially soluble in aromatic solvent once isolated, and it decomposes in polar solvents. ATR-IR $v / \mathrm{cm}^{-1}$ : 2935 (br, w), 2857 (m), 2828 (w), $1460(\mathrm{~m}), 1357(\mathrm{w}), 1272(\mathrm{w}), 1116(\mathrm{w}), 1066(\mathrm{~m}), 1008(\mathrm{w}), 933(\mathrm{~s}), 880(\mathrm{~s}), 736(\mathrm{vs})$ 
$670(\mathrm{~s}), 626(\mathrm{~m}), 558(\mathrm{w}), 507(\mathrm{w}), 442(\mathrm{w})$. The NH stretching absorption was not observed.

Preparation of [U(TrenTIPS)( $\mu-\mathbf{N H})(\boldsymbol{\mu}-\mathbf{R b})\left(\mathbf{M e}_{6}-\right.$ Tren)] (3Rb). Method A: A solution of $\mathrm{Me}_{6}$-Tren $(0.17 \mathrm{~g}, 0.75 \mathrm{mmol})$ in toluene $(5 \mathrm{ml})$ was added slowly to a pre-cooled $\left(-78^{\circ} \mathrm{C}\right)$ mixture of $\mathrm{RbCH}_{2} \mathrm{Ph}(0.097 \mathrm{~g}, 0.55 \mathrm{mmol})$ in toluene $(10 \mathrm{ml})$. After $30 \mathrm{~min}$, a solution of $1(0.43 \mathrm{~g}, 0.50 \mathrm{mmol})$ in toluene $(10 \mathrm{ml})$ was added at $-78{ }^{\circ} \mathrm{C}$. The mixture was allowed to warm to room temperature and stirred for further $16 \mathrm{~h}$, forming a red solution. The mixture was filtered and concentrated to $5 \mathrm{ml}$. Pink crystals of $\mathbf{3 R} \mathbf{R}$ were obtained by storing the resulting red solution at $-30{ }^{\circ} \mathrm{C}$ for 2 days. Yield: $0.33 \mathrm{~g}, 56 \%$. Method B: $\mathrm{Me}_{6}$-Tren $(0.17 \mathrm{~g}, 0.75 \mathrm{mmol})$ was added to the pink suspension of $2 \mathbf{R b}(0.48 \mathrm{~g}, 0.25 \mathrm{mmol})$ in toluene $(20 \mathrm{ml})$ and the mixture was stirred for $24 \mathrm{~h}$ at room temperature. Volatiles were removed from the resulting red solution in vacuo. The pink residue was washed with pentane $(2 \times 5$ $\mathrm{mL}$ ) and dried in vacuo, giving $\mathbf{3 R \mathbf { b }}$ as a pure pink solid. Yield: $0.40 \mathrm{~g}, 68 \%$. Anal. Calcd for $\mathrm{C}_{45} \mathrm{H}_{106} \mathrm{RbN}_{9} \mathrm{Si}_{3} \mathrm{U}$ : C, 45.76; H, 9.05; N, 10.67\%. Found: C, 45.71; H, 9.29; $\mathrm{N}, 10.54 \% .{ }^{1} \mathrm{H}$ NMR $\left(400 \mathrm{MHz}, \mathrm{C}_{6} \mathrm{D}_{6}, 298 \mathrm{~K}\right): \delta-23.24\left(\mathrm{br}, 54 \mathrm{H}, \mathrm{CH}\left(\mathrm{CH}_{3}\right)_{2}\right)$, -21.08 (br, 9H, $\left.\mathrm{CH}\left(\mathrm{CH}_{3}\right)_{2}\right), 8.54$ (br, $\left.12 \mathrm{H}, \mathrm{CH}_{2}-\mathrm{Me}_{6}-\mathrm{TREN}\right), 11.03$ (br, $18 \mathrm{H}$, $\left.\mathrm{N}\left(\mathrm{CH}_{3}\right)_{2}\right), 16.54$ (br, $6 \mathrm{H}, \mathrm{NCH}_{2} \mathrm{CH}_{2}$ ), 106.59 (br, $6 \mathrm{H}, \mathrm{NCH}_{2} \mathrm{CH}_{2}$ ). The $\mathrm{NH}$ resonance was not observed in the ${ }^{1} \mathrm{H}$ NMR spectrum. Reliable ${ }^{29} \mathrm{Si}$ NMR and UV/Vis/ NIR spectra and solution magnetic moment (Evan's method) could not be obtained, due to $\mathbf{3 R \mathbf { b }}$ being only partially soluble in aromatic solvent once isolated, and it decomposes in polar solvents. ATR-IR $v / \mathrm{cm}^{-1}: 2934(\mathrm{br}, \mathrm{w}), 2880(\mathrm{~m}), 2821$ (w), $1460(\mathrm{~m}), 1339(\mathrm{w}), 1274(\mathrm{w}), 1117(\mathrm{w}), 1070(\mathrm{~m}), 1010(\mathrm{w}), 931(\mathrm{~s}), 881$ (s), $736(\mathrm{vs}), 670(\mathrm{~s}), 624(\mathrm{~m}), 539(\mathrm{w}), 508(\mathrm{w}), 440(\mathrm{w})$. The NH stretching absorption was not observed.

\section{Preparation of [U(Tren TIPS)( $\mu-\mathbf{N H})(\mu-\mathrm{Cs})\left(\mathbf{M e}_{6}-\right.$ Tren)] (3Cs). Method A: A} solution of $\mathrm{Me}_{6}$-Tren $(0.17 \mathrm{~g}, 0.75 \mathrm{mmol})$ in toluene $(5 \mathrm{ml})$ was added slowly to a pre-cooled $\left(-78^{\circ} \mathrm{C}\right)$ mixture of $\mathrm{CsCH}_{2} \mathrm{Ph}(0.12 \mathrm{~g}, 0.55 \mathrm{mmol})$ in toluene $(10 \mathrm{ml})$. After $30 \mathrm{~min}$, a solution of $1(0.43 \mathrm{~g}, 0.50 \mathrm{mmol})$ in toluene $(10 \mathrm{ml})$ was added at $-78{ }^{\circ} \mathrm{C}$. The mixture was allowed to warm up to room temperature and stirred for further $16 \mathrm{~h}$, forming a dark red brown solution. The mixture was filtered and concentrated to $3 \mathrm{ml}$. Pink crystals of $3 \mathrm{Cs}$ were obtained by storing the resulting dark red brown solution in at $-30{ }^{\circ} \mathrm{C}$ for 2 days. Yield: $0.22 \mathrm{~g}, 35 \%$. Method B: $\mathrm{Me}_{6}$-Tren $(0.17 \mathrm{~g}, 0.75 \mathrm{mmol})$ was added to a pink suspension of $2 \mathrm{Cs}(0.50 \mathrm{~g}, 0.25$ $\mathrm{mmol})$ in toluene $(20 \mathrm{ml})$ and the reaction was stirred for $24 \mathrm{~h}$ at room temperature. Volatiles were removed from the resulting dark red brown solution in vacuo. The mixture was washed with pentane $(2 \times 5 \mathrm{~mL})$ and dried in vacuo, giving $3 \mathrm{Cs}$ as a pure pink solid. Yield: $0.38 \mathrm{~g}, 60 \%$. Anal. Calcd for $\mathrm{C}_{45} \mathrm{H}_{106} \mathrm{CsN}_{9} \mathrm{Si}_{3} \mathrm{U}$ : C, 43.99; $\mathrm{H}$, 8.70 ; N, $10.26 \%$. Found: C, 43.75; H, 8.89; N, 9.78\%. ${ }^{1} \mathrm{H} \mathrm{NMR}\left(400 \mathrm{MHz}, \mathrm{C}_{6} \mathrm{D}_{6}\right.$, $298 \mathrm{~K}$ ): $\delta-23.06\left(\mathrm{br}, 54 \mathrm{H}, \mathrm{CH}\left(\mathrm{CH}_{3}\right)_{2}\right),-22.03\left(\mathrm{br}, 9 \mathrm{H}, \mathrm{CH}\left(\mathrm{CH}_{3}\right)_{2}\right), 8.53$ (br, $6 \mathrm{H}$, $\mathrm{CH}_{2}-\mathrm{Me}_{6}$-TREN), 8.61 (br, 6H, $\mathrm{CH}_{2}-\mathrm{Me}_{6}$-TREN), 10.83 (br, 18H, N $\left.\left(\mathrm{CH}_{3}\right)_{2}\right), 16.87$ (br, $6 \mathrm{H}, \mathrm{NCH}_{2} \mathrm{CH}_{2}$ ), 108.04 (br, $6 \mathrm{H}, \mathrm{NCH}_{2} \mathrm{CH}_{2}$ ). The $\mathrm{NH}$ resonance was not observed in the ${ }^{1} \mathrm{H}$ NMR spectrum. ${ }^{29} \mathrm{Si}\left\{{ }^{1} \mathrm{H}\right\}$ NMR $\left(79 \mathrm{MHz}, \mathrm{C}_{6} \mathrm{D}_{6}, 298 \mathrm{~K}\right): \delta$

-166.29 (br). ATR-IR v/cm ${ }^{-1}$ : 2937 (br, w), 2856 (m), 2823 (w), 1459 (m), 1357 (w), $1272(\mathrm{w}), 1118(\mathrm{w}), 1070(\mathrm{~m}), 1010(\mathrm{w}), 932(\mathrm{~s}), 880$ (s), 733 (vs), 670 (s), 626 (m), $560(\mathrm{w}), 505(\mathrm{w}), 441(\mathrm{w})$. The NH stretching absorption was not observed. $\mu_{\text {eff }}$ (Evans method, $\left.\mathrm{C}_{6} \mathrm{D}_{6}, 298 \mathrm{~K}\right): 2.9 \mu_{\mathrm{B}}$.

Preparation of [U(Tren $\left.{ }^{\text {TIPS }}\right)(\boldsymbol{\mu}-\mathbf{N})(\boldsymbol{\mu}-\mathrm{Li})\left(\mathbf{M e}_{\mathbf{6}}-\right.$ Tren $\left.)\right]$ (5Li). $\mathrm{Me}_{6}$-Tren $(0.17 \mathrm{~g}$, $0.75 \mathrm{mmol})$ was added to a red suspension of $4 \mathrm{Li}(0.44 \mathrm{~g}, 0.25 \mathrm{mmol})$ in toluene $(20 \mathrm{ml})$ and the mixture was stirred for $24 \mathrm{~h}$ at room temperature. Volatiles were removed from the resulting red solution in vacuo. The mixture was extracted into pentane $(5 \mathrm{ml})$, filtered, and the dark red filtrate was stored at $-30^{\circ} \mathrm{C}$ for 2 days to yield dark red crystals of $\mathbf{5} \mathbf{L i}$, which was isolated by decanting the mother liquor and dried in vacuo. Yield: $0.38 \mathrm{~g}, 68 \%$. Anal. Calcd for $\mathrm{C}_{45} \mathrm{H}_{105} \mathrm{LiN}_{9} \mathrm{Si}_{3} \mathrm{U}$ : C, 49.06; H, 9.61; N, 11.44\%. Found: C, 49.13; H, 10.13; N, $11.23 \% .{ }^{1} \mathrm{H}$ NMR $(400 \mathrm{MHz}$, $\left.\mathrm{C}_{6} \mathrm{D}_{6}, 298 \mathrm{~K}\right): \delta-26.27\left(\mathrm{~s}, 9 \mathrm{H}, \mathrm{CH}\left(\mathrm{CH}_{3}\right)_{2}\right),-8.01\left(\mathrm{~s}, 54 \mathrm{H}, \mathrm{CH}\left(\mathrm{CH}_{3}\right)_{2}\right), 7.50(\mathrm{br}$, $6 \mathrm{H}, \mathrm{NCH}_{2} \mathrm{CH}_{2}$ ), 9.24 (br, $\left.18 \mathrm{H}, \mathrm{N}\left(\mathrm{CH}_{3}\right)_{2}\right), 9.95$ (br, 6H, $\left.\mathrm{CH}_{2}-\mathrm{Me}_{6}-\mathrm{TREN}\right), 13.55$ (br, 6H, $\left.\mathrm{CH}_{2}-\mathrm{Me}_{6}-\mathrm{TREN}\right), 41.70$ (br, $\left.6 \mathrm{H}, \mathrm{NCH}_{2} \mathrm{CH}_{2}\right) .{ }^{7} \mathrm{Li}\left\{{ }^{1} \mathrm{H}\right\}(155 \mathrm{MHz}, 298 \mathrm{~K}$, $\left.\mathrm{C}_{6} \mathrm{D}_{6}\right): \delta$ not observed. ${ }^{29} \mathrm{Si}\left\{{ }^{1} \mathrm{H}\right\} \mathrm{NMR}\left(79 \mathrm{MHz}, \mathrm{C}_{6} \mathrm{D}_{6}, 298 \mathrm{~K}\right): \delta-15.38$. FTIR $v / \mathrm{cm}^{-1}$ : 2936 (br, w), $2856(\mathrm{~m}), 2831(\mathrm{w}), 1456(\mathrm{~m}), 1354(\mathrm{w}), 1293(\mathrm{w}), 1272(\mathrm{w})$, $1114(\mathrm{w}), 1058$ (m), 1011 (w), 930 (s), 880 (s), 782 (w), 728 (vs), 669 (s), 625 (m), $564(\mathrm{w}), 510(\mathrm{w}), 444(\mathrm{w}) \cdot \mu_{\mathrm{eff}}$ (Evan's method, $\left.\mathrm{C}_{6} \mathrm{D}_{6}, 298 \mathrm{~K}\right): 1.6 \mu_{\mathrm{B}}$.

Preparation of $\left[\mathrm{U}\left(\right.\right.$Trren$\left.^{\text {TIPS }}\right)(\boldsymbol{\mu}-\mathbf{N})(\boldsymbol{\mu}-\mathbf{N a})\left(\mathbf{M e}_{6}-\right.$ Tren $\left.)\right]$ (5Na). $\mathrm{Me}_{6}-$ Tren $(0.17 \mathrm{~g}$, $0.75 \mathrm{mmol})$ was added to a red suspension of $4 \mathrm{Na}(0.45 \mathrm{~g}, 0.25 \mathrm{mmol})$ in toluene $(20 \mathrm{ml})$ and the reaction was stirred for $24 \mathrm{~h}$ at room temperature. Volatiles were removed from the resulting red solution in vacuo. The product was extracted into hot toluene $\left(80^{\circ} \mathrm{C}, 10 \mathrm{ml}\right)$, filtered, and the dark red filtrate was stored at $-30^{\circ} \mathrm{C}$ for $16 \mathrm{~h}$ to yield dark red crystals of $5 \mathrm{Na}$ which was isolated by decanting the mother liquor and dried in vacuo. Yield: $0.23 \mathrm{~g}, 41 \%$. Anal. Calcd for $\mathrm{C}_{45} \mathrm{H}_{105} \mathrm{NaN}_{9} \mathrm{Si}_{3} \mathrm{U}$ : C, 48.36; H, 9.47; N, 11.28\%. Found: C, 48.31; H, 9.79; N, $10.51 \% .{ }^{1} \mathrm{H}$ NMR $\left(400 \mathrm{MHz}, \mathrm{C}_{6} \mathrm{D}_{6}, 298 \mathrm{~K}\right): \delta-25.05$ (s, 9H, $\left.\mathrm{CH}\left(\mathrm{CH}_{3}\right)_{2}\right),-7.69$ (s, $\left.54 \mathrm{H}, \mathrm{CH}\left(\mathrm{CH}_{3}\right)_{2}\right), 7.89$ (br, $6 \mathrm{H}, \mathrm{NCH}_{2} \mathrm{CH}_{2}$ ), 8.83 (br, $6 \mathrm{H}, \mathrm{CH}_{2}-\mathrm{Me}_{6}-\mathrm{TREN}$ ), 9.60 (br, $18 \mathrm{H}, \mathrm{N}\left(\mathrm{CH}_{3}\right)_{2}$ ), 9.95 (br, $6 \mathrm{H}, \mathrm{CH}_{2}-\mathrm{Me}_{6}-\mathrm{TREN}$ ), 41.21 (br, $6 \mathrm{H}, \mathrm{NCH}_{2} \mathrm{CH}_{2}$ ). ATR-IR $v / \mathrm{cm}^{-1}: 2935$ (br, w), 2857 (m), $2826(\mathrm{w}), 1458$ (m), 1356 (w), 1300 (w), $1274(\mathrm{w}), 1224(\mathrm{w}), 1161(\mathrm{w}), 1116(\mathrm{~m}), 1026(\mathrm{w}), 934(\mathrm{~s}), 878(\mathrm{~s}), 783(\mathrm{w}), 732$ (vs), 670 (s), 627 (m), 563 (w), 510 (w), 444 (w). Reliable ${ }^{29}$ Si NMR and UV/Vis/ NIR spectra and solution magnetic moment (Evan's method) could not be obtained as $\mathbf{5 N a}$ is only partially soluble in aromatic solvent once isolated, and it decomposes in polar solvents.

Preparation of $\left[\mathbf{U}\left(\right.\right.$ Tren $\left.\left.^{\text {TIPS }}\right)(\boldsymbol{\mu}-\mathbf{N})(\boldsymbol{\mu}-\mathbf{K})\left(\mathbf{M e}_{\mathbf{6}}-\mathbf{T r e n}\right)\right](\mathbf{5 K})$. Benzene $(60 \mathrm{ml})$ was added slowly to a pre-cooled $\left(-78^{\circ} \mathrm{C}\right)$ mixture of $1(0.87 \mathrm{~g}, 1.00 \mathrm{mmol})$ and $\mathrm{KCH}_{2} \mathrm{Ph}(0.13 \mathrm{~g}, 1.00 \mathrm{mmol})$. The frozen mixture was allowed to thaw to room temperature and stirred for $24 \mathrm{~h}$, resulting in a pink suspension. The mixture was assayed by ${ }^{1} \mathrm{H}$ NMR spectroscopy, confirming that $\mathbf{1}$ was completely consumed and converted to $2 \mathrm{~K}$. The mixture was then heated to $80^{\circ} \mathrm{C}$ for $30 \mathrm{~min}$, and the mixture turned dark red. Dark red crystals of $4 \mathrm{~K}$ started to form upon cooling the mother liquor, which was left to further crystallise at $10^{\circ} \mathrm{C}$ for $16 \mathrm{~h}$. The identity of 4K was confirmed by crystallographic unit cell check. Yield: $0.27 \mathrm{~g}, 30 \%$ (based on uranium). Removal of the volatiles from the mother liquor in vacuo gave a pale brown solid containing $\mathbf{1}$ as the main product by ${ }^{1} \mathrm{H}$ NMR spectroscopy. Pentane $(2 \mathrm{ml})$ was added to the brown residue, and after filtration, a brown solution was obtained. Storing the solution at $-30^{\circ} \mathrm{C}$ for $24 \mathrm{~h}$ gave brown crystals 1 , which were isolated by filtration and dried in vacuo. Yield: $0.41 \mathrm{~g}, 47 \%$ (based on uranium). If the ratio of $\mathrm{KCH}_{2} \mathrm{Ph}$ is increased (by $1.5,2.0$, or even 3.0) in the first step, $4 \mathrm{~K}$ can be isolated in higher yield ( $52 \%$, based on uranium), accompanied by a lower yield of $\mathbf{1}(28 \%$, based on uranium) isolated from the mother liquor. The crystalline $4 \mathrm{~K}$ was slurried in benzene $(15 \mathrm{ml})$, and $\mathrm{Me}_{6}$-Tren $(0.10 \mathrm{~g}, 0.45 \mathrm{mmol})$ was added. The mixture was stirred for $24 \mathrm{~h}$ at room temperature. The red solution was concentrated to $5 \mathrm{ml}$ and filtered. Slow evaporation of the red solution in a glove box afforded dark red crystals of $\mathbf{5 K}$ which were isolated by filtration and dried in vacuo. Yield: $0.21 \mathrm{~g}, 62 \%$. Utilising authentic $4 \mathrm{~K}$ produced $5 \mathrm{~K}$ with an identical result. Anal. Calcd for $\mathrm{C}_{45} \mathrm{H}_{105} \mathrm{KN}_{9} \mathrm{Si}_{3} \mathrm{U}$ : C, 47.67; H, 9.34; N, $11.12 \%$. Found: $\mathrm{C}$, 47.44; H, 9.69; N, 10.92\%. ${ }^{1} \mathrm{H}$ NMR (400 MHz, $\left.\mathrm{C}_{6} \mathrm{D}_{6}, 298 \mathrm{~K}\right): \delta-23.81$ (s, $9 \mathrm{H}, \mathrm{CH}$ $\left.\left(\mathrm{CH}_{3}\right)_{2}\right),-6.92\left(\mathrm{~s}, 54 \mathrm{H}, \mathrm{CH}\left(\mathrm{CH}_{3}\right)_{2}\right), 6.85\left(\mathrm{br}, 30 \mathrm{H}, \mathrm{CH}_{2} \mathrm{CH}_{2} \mathrm{~N}\left(\mathrm{CH}_{3}\right)_{2}\right), 8.80(\mathrm{br}$, $6 \mathrm{H}, \mathrm{NCH}_{2} \mathrm{CH}_{2}$ ), 40.47 (br, 6H, $\mathrm{NCH}_{2} \mathrm{CH}_{2}$ ). FTIR $v / \mathrm{cm}^{-1}: 2934$ (br, w), 2855 (m), $2824(\mathrm{w}), 1460(\mathrm{~m}), 1356(\mathrm{w}), 1310(\mathrm{w}), 1271(\mathrm{w}), 1251(\mathrm{w}), 1157(\mathrm{w}), 1068(\mathrm{~m})$, $1009(\mathrm{w}), 931$ (s), 879 (s), $786(\mathrm{w}), 730(\mathrm{vs}), 668(\mathrm{~s}), 626(\mathrm{~m}), 561(\mathrm{w}), 507(\mathrm{w}), 443$ (w). Reliable ${ }^{29} \mathrm{Si} \mathrm{NMR}$ and UV/Vis/NIR spectra and solution magnetic moment (Evan's method) could not be obtained as $\mathbf{5 K}$ is only partially soluble in aromatic solvent once isolated, and it decomposes in polar solvents.

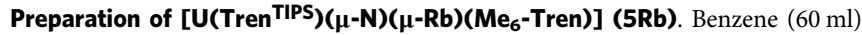
was added slowly to a pre-cooled $\left(-78^{\circ} \mathrm{C}\right)$ mixture of $\mathbf{1}(0.87 \mathrm{~g}, 1.00 \mathrm{mmol})$ and $\mathrm{RbCH}_{2} \mathrm{Ph}(0.18 \mathrm{~g}, 1.00 \mathrm{mmol})$. The frozen mixture was left to thaw to room temperature and stirred for $24 \mathrm{~h}$, resulting in a pink suspension. The mixture was then heated to $80^{\circ} \mathrm{C}$ for $30 \mathrm{~min}$, and the resulting red suspension was filtered to give a dark red solution. Dark red crystals of $\mathbf{4 R \mathbf { R }}$ started to form upon cooling the mother liquor, which was left to further crystallise at $10^{\circ} \mathrm{C}$ for $16 \mathrm{~h}$. The identity of 4Rb was confirmed by crystallographic unit cell check. Yield: $0.22 \mathrm{~g}$, 24\% (based on uranium). The crystalline $\mathbf{4} \mathbf{R b}$ was slurried in benzene $(15 \mathrm{ml})$, and $\mathrm{Me}_{6}$-Tren $(0.08 \mathrm{~g}, 0.36 \mathrm{mmol})$ was added. The mixture was stirred for $24 \mathrm{~h}$ at room temperature. The red solution was concentrated to $5 \mathrm{ml}$ and filtered. Slow evaporation of the red solution in a glovebox afforded dark red crystals of $\mathbf{5} \mathbf{R} \mathbf{b}$ which were isolated by filtration and dried in vacuo. Yield: $0.22 \mathrm{~g}$, 76\%. Utilising authentic $4 \mathbf{R b}$ produced $\mathbf{5 R b}$ with an identical result. Anal. Calcd for $\mathrm{C}_{45} \mathrm{H}_{105} \mathrm{RbN}_{9} \mathrm{Si}_{3} \mathrm{U}$ : C, 45.80; $\mathrm{H}, 8.97$; N, 10.68\%. Found: C, 45.94; H, 9.30; N, 10.51\%. ${ }^{1} \mathrm{H}$ NMR (400 MHz, ${ }_{6} \mathrm{D}_{6}$, $298 \mathrm{~K}): \delta-23.08\left(\mathrm{~s}, 9 \mathrm{H}, \mathrm{CH}\left(\mathrm{CH}_{3}\right)_{2}\right),-6.46\left(\mathrm{~s}, 54 \mathrm{H}, \mathrm{CH}\left(\mathrm{CH}_{3}\right)_{2}\right), 6.28(\mathrm{br}, 6 \mathrm{H}$, $\mathrm{CH}_{2}-\mathrm{Me}_{6}$-TREN), 6.45 (br, $6 \mathrm{H}, \mathrm{CH}_{2}-\mathrm{Me}_{6}$-TREN), 8.04 (br, 24H, $\mathrm{NCH}_{2} \mathrm{CH}_{2}$ and $\left.\mathrm{N}\left(\mathrm{CH}_{3}\right)_{2}\right), 39.27$ (br, 6H, $\left.\mathrm{NCH}_{2} \mathrm{CH}_{2}\right)$. FTIR $v / \mathrm{cm}^{-1}: 2934$ (br, w), $2855(\mathrm{~m}), 2824$ $(\mathrm{w}), 1460(\mathrm{~m}), 1357(\mathrm{w}), 1301(\mathrm{w}), 1156(\mathrm{w}), 1116(\mathrm{w}), 1069(\mathrm{~m}), 1009(\mathrm{w}), 931(\mathrm{~s})$ 879 (s), 787 (w), 731 (vs), 668 (s), 625 (m), 561 (w), 506 (w), 443 (w). Reliable ${ }^{29}$ S NMR and UV/Vis/NIR spectra and solution magnetic moment (Evan's method) could not be obtained as $\mathbf{5 R \mathbf { R }}$ is only partially soluble in aromatic solvent once isolated, and it decomposes in coordinative or polar solvents.

Preparation of [U(Tren $\left.{ }^{\text {TIPS }}\right)(\boldsymbol{\mu}-\mathbf{N})(\boldsymbol{\mu}-\mathbf{C s})\left(\mathbf{M e}_{\mathbf{6}}-\right.$ Tren)] (5Cs). Benzene (30 ml) was added slowly to a pre-cooled $\left(-78^{\circ} \mathrm{C}\right)$ mixture of $\mathbf{1}(0.87 \mathrm{~g}, 1.00 \mathrm{mmol})$ and $\mathrm{CsCH}_{2} \mathrm{Ph}(0.34 \mathrm{~g}, 1.5 \mathrm{mmol})$. The frozen mixture was left to thaw to room temperature and stirred for $24 \mathrm{~h}$, resulting in a pink suspension. The mixture was then heated to $80^{\circ} \mathrm{C}$ for $30 \mathrm{~min}$, and the resulting red suspension was filtered to give a red solution. Dark red crystals of 4 Cs started to form upon cooling the mother liquor, which was left to further crystallise at $10^{\circ} \mathrm{C}$ for $16 \mathrm{~h}$. The identity of $4 \mathrm{Cs}$ was confirmed by crystallographic unit cell check. Yield: $0.18 \mathrm{~g}, 18 \%$ (based on uranium). The crystalline $4 \mathrm{Cs}$ was slurried in benzene $(15 \mathrm{ml})$, and $\mathrm{Me}_{6}$-Tren $(0.06 \mathrm{~g}$, $0.27 \mathrm{mmol}$ ) was added. The mixture was stirred for $24 \mathrm{~h}$ at room temperature. Volatiles were removed from the resulting red brown solution in vacuo. The red brown residue was washed with pentane $(5 \mathrm{ml})$, and then extracted into toluene (5 $\mathrm{ml}$ ), filtered, concentrated to $2 \mathrm{ml}$, and then stored at $-30^{\circ} \mathrm{C}$ for $16 \mathrm{~h}$ to yield dark red crystals of $\mathbf{5 C s}$ which were isolated by filtration and dried in vacuo. Yield: 0.10 g, 46\%. Utilising authentic 4Cs produced $5 \mathrm{Cs}$ with an identical result. Anal. Calcd for $\mathrm{C}_{45} \mathrm{H}_{105} \mathrm{CsN}_{9} \mathrm{Si}_{3} \mathrm{U}$ : C, 44.03; H, 8.62; N, 10.27\%. Found: C, 43.85; H, 8.92; N, 10.08\%. ${ }^{1} \mathrm{H}$ NMR (400 MHz, $\left.\mathrm{C}_{6} \mathrm{D}_{6}, 298 \mathrm{~K}\right): \delta-22.57$ (br, d, $\left.9 \mathrm{H}, \mathrm{CH}\left(\mathrm{CH}_{3}\right)_{2}\right),-5.98$ (s, 54H, $\left.\mathrm{CH}\left(\mathrm{CH}_{3}\right)_{2}\right), 4.03$ (br, 6H, $\mathrm{CH}_{2}-\mathrm{Me}_{6}-\mathrm{TREN}$ ), 4.20 (br, $6 \mathrm{H}, \mathrm{CH}_{2}-\mathrm{Me}_{6}$ - 
TREN), 4.45 (br, 18H, N( $\left.\left.\mathrm{CH}_{3}\right)_{2}\right), 8.14$ (br, $6 \mathrm{H}, \mathrm{NCH}_{2} \mathrm{CH}_{2}$ ), 37.45 (br, $6 \mathrm{H}$ $\left.\mathrm{NCH}_{2} \mathrm{CH}_{2}\right) .{ }^{29} \mathrm{Si}\left\{{ }^{1} \mathrm{H}\right\}$ NMR $\left(79 \mathrm{MHz}, \mathrm{C}_{6} \mathrm{D}_{6}, 298 \mathrm{~K}\right): \delta-17.00$. FTIR $v / \mathrm{cm}^{-1}: 2935$ (br, w), $2880(\mathrm{~m}), 2822(\mathrm{w}), 1460(\mathrm{~m}), 1357(\mathrm{w}), 1303(\mathrm{w}), 1155(\mathrm{w}), 1118(\mathrm{w}), 1071$ (m), $1010(\mathrm{w}), 930(\mathrm{~s}), 880(\mathrm{~s}), 786(\mathrm{w}), 729(\mathrm{vs}), 667(\mathrm{~m}), 626(\mathrm{~m}), 561(\mathrm{w}), 506$ (w), 443 (w). $\mu_{\text {eff }}$ (Evan's method, $\left.\mathrm{C}_{6} \mathrm{D}_{6}, 298 \mathrm{~K}\right): 2.3 \mu_{\mathrm{B}}$.

Computational details. All calculations were carried out at the DFT level of theory using the hybrid functional B3PW9159,60, with the Gaussian 09 suite of programmes ${ }^{61}$. The $\mathrm{U}, \mathrm{Th}, \mathrm{Si}$ and $\mathrm{Cs}$ atoms were represented with a small-core Stuttgart-Dresden relativistic effective core potential associated with their adapted basis set ${ }^{62-64}$. All the other atoms $\mathrm{Li}, \mathrm{C}, \mathrm{H}$, and $\mathrm{N}$ were described with a $6-31 \mathrm{G}(\mathrm{d}, \mathrm{p})$, double- $\zeta$ quality basis set ${ }^{65-68}$. The nature of the extrema (minimum) was established with analytical frequencies calculations and geometry optimisations were computed without any symmetry constraints. The SMD solvation model was used to evaluate solvation energies by a self-consistent reaction field approach based on accurate numerical solutions of the Poisson-Boltzmann equation ${ }^{69}$. Benzene was chosen as solvent. The enthalpy energy was computed at $T=298 \mathrm{~K}$. Intrinsic Reaction Coordinates were carried out to verify the connections of the optimised transition states.

\section{Data availability}

The X-ray crystallographic data for $\mathbf{3} \mathbf{M}$ and $\mathbf{5 M}$ reported in this study have been deposited at the Cambridge Crystallographic Data Centre under accession codes 1997349-1997358. These data can be obtained free of charge from The Cambridge Crystallographic Data Centre (www.ccdc.cam.ac.uk/data_request/cif). All the other data supporting the findings of this study are available within the article, its Supplementary Information (Supplementary Figs. 1-45 and Tables 1-47), or from the corresponding authors upon reasonable request. Source data are available from the authors upon reasonable request.

Received: 14 May 2020; Accepted: 21 July 2021;

Published online: 10 August 2021

\section{References}

1. Atkins, P. W., Rouke, J., Armstrong, F., Weller, M. \& Overton, T. Inorganic Chemistry. (Oxford University Press, 2009).

2. Gadolin, J. K. On the ability of copper to precipitate tin from its solutions in tartric acid. Sv. Vet. Acad. Handl. 186-197 (1788).

3. Herasymenko, P. Electroreduction of uranyl salts by means of the mercury dropping cathode. Trans. Faraday Soc. 24, 272-279 (1928).

4. Kern, D. M. H. \& Orlemann, E. F. The potential of the uranium(V), uranium (VI) couple and the kinetics of uranium(V) disproportionation in perchlorate media. J. Am. Chem. Soc. 71, 2102-2106 (1949).

5. Kraus, K. A., Nelson, F. \& Johnson, G. L. Chemistry of aqueous uranium(V) solutions. I. Preparation and properties. Analogy between uranium(V), neptunium(V) and plutonium(V). J. Am. Chem. Soc. 71, 2510-2517 (1949).

6. Runnalls, O. J. C. A new synthesis of uranium trifluoride. Can. J. Chem. 31, 694-696 (1953).

7. Jones, M. B. \& Gaunt, A. J. Recent developments in synthesis and structural chemistry of nonaqueous actinide complexes. Chem. Rev. 113, 1137-1198 (2013).

8. La Pierre, H. S. \& Meyer, K. Activation of small molecules by molecular uranium complexes. Prog. Inorg. Chem. 58, 303-416 (2014).

9. Liddle, S. T. The renaissance of non-aqueous uranium chemistry. Angew. Chem. Int. Ed. 54, 8604-8641 (2015).

10. Lovley, D. R., Phillips, E. J. P., Gorby, Y. A. \& Landa, E. R. Microbial reduction of uranium. Nature 350, 413-416 (1991).

11. Renshaw, J. C. et al. Bioreduction of uranium: environmental implications of a pentavalent intermediate. Environ. Sci. Tech. 39, 5657-5660 (2005).

12. Altmaier, M., Gaona, X. \& Fanghänel, T. Recent advances in aqueous actinide chemistry and thermodynamics. Chem. Rev. 113, 901-943 (2013).

13. Natrajan, L. S., Swinburne, A. N., Andrews, M. B., Randall, S. \& Heath, S. L. Redox and environmentally relevant aspects of actinide(IV) coordination chemistry. Coord. Chem. Rev. 266-267, 171-193 (2014).

14. Falcone, M., Kefalidis, C. E., Scopelliti, R., Maron, L. \& Mazzanti, M. Facile $\mathrm{CO}$ cleavage by a multimetallic $\mathrm{CsU}_{2}$ nitride complex. Angew. Chem. Int. Ed. 55, 12290-12294 (2016).

15. Brennan, J. G., Andersen, R. A. \& Zalkin, A. Crystal structures of $\left(\mathrm{MeC}_{5} \mathrm{H}_{4}\right)_{4} \mathrm{U}_{2}(\mu-\mathrm{NR})_{2}$. Unsymmetrical bridging, $\mathrm{R}=\mathrm{Ph}$, and symmetrical bridging, $\mathrm{R}=\mathrm{SiMe}_{3}$, organoimide ligands in organoactinide compounds. $J$. Am. Chem. Soc. 110, 4554-4558 (1988).

16. Steele, H. \& Taylor, R. J. A theoretical study of the inner-sphere disproportionation reaction mechanism of the pentavalent actinyl ions. Inorg. Chem. 46, 6311-6318 (2007)

17. King, D. M. et al. Synthesis and characterization of an f-block terminal parent imido $[\mathrm{U}=\mathrm{NH}$ ] complex: a masked uranium(IV)-nitride. J. Am. Chem. Soc. 136, 5619-5622 (2014)
18. King, D. M. et al. Molecular and electronic structure of terminal and alkali metal-capped uranium(V)-nitride complexes. Nat. Commun. 7, 13773 (2016).

19. Cleaves, P. A. et al. Two-electron reductive carbonylation of terminal uranium (V) and uranium(VI) nitrides to cyanate by carbon monoxide. Angew. Chem. Int. Ed. 53, 10412-10415 (2014).

20. King, D. M. et al. Synthesis and structure of a terminal uranium nitride complex. Science 337, 717-720 (2012).

21. King, D. M. et al. Isolation and characterisation of a uranium(VI)-nitride triple bond. Nat. Chem. 5, 482-488 (2013).

22. Pyykkö, P. Additive covalent radii for single-, double-, and triple-bonded molecules and tetrahedrally bonded crystals: a summary. J. Phys. Chem. A 119, 2326-2337 (2015).

23. Castro-Rodríguez, I. \& Meyer, K. Small molecule activation at uranium coordination complexes: control of reactivity via molecular architecture. Chem. Commun. 1353-1368 (2006).

24. Kindra, D. R. \& Evans, W. J. Magnetic susceptibility of uranium complexes. Chem. Rev. 114, 8865-8882 (2014).

25. Lu, E., Boronski, J. T., Gregson, M., Wooles, A. J. \& Liddle, S. T. Silylphosphino-carbene complexes of uranium(IV). Angew. Chem. Int. Ed. 57, 5506-5511 (2018).

26. Gregson, M. et al. The inverse-trans-influence in tetravalent lanthanide and actinide bis(carbene) complexes. Nat. Commun. 8, 14137 (2017).

27. Rookes, T. M. et al. Crystalline diuranium-phosphinidiide and - $\mu$-phosphido complexes with symmetric and asymmetric UPU cores. Angew. Chem. Int. Ed. 56, 10495-10500 (2017)

28. Gardner, B. M. et al. Triamidoamine uranium(IV)-arsenic complexes containing one-, two-, and three-fold U-As bonding interactions. Nat. Chem. 7, 582-590 (2015).

29. Brown, J. L., Fortier, S., Lewis, R. A., Wu, G. \& Hayton, T. W. A complete family of terminal uranium chalcogenides, $\left[\mathrm{U}(\mathrm{E})\left(\mathrm{N}\left\{\mathrm{SiMe}_{3}\right\}_{2}\right)_{3}\right]^{-}(\mathrm{E}=\mathrm{O}, \mathrm{S}, \mathrm{Se}$ Te). J. Am. Chem. Soc. 134, 15468-15475 (2012).

30. Halter, D. P., La Pierre, H. S., Heinemann, F. W. \& Meyer, K. Uranium(IV) halide $\left(\mathrm{F}^{-}, \mathrm{Cl}^{-}, \mathrm{Br}^{-}\right.$, and $\left.\mathrm{I}^{-}\right)$monoarene complexes. Inorg. Chem. 53, 8418-8424 (2014)

31. Newell, B. S., Rappé, A. K. \& Shores, M. P. Experimental evidence for magnetic exchange in di- and trinuclear uranium(IV) ethynylbenzene complexes. Inorg. Chem. 49, 1595-1606 (2010).

32. Rinehart, J. D., Harris, T. D., Kozimor, S. A., Bartlett, B. M. \& Long, J. R. Magnetic exchange coupling in actinide-containing molecules. Inorg. Chem. 48, 3382-3395 (2009).

33. Gardner, B. M. et al. Assessing crystal field and magnetic interactions in diuranium- $\mu$-chalcogenide triamidoamine complexes with $\mathrm{U}^{\mathrm{IV}}-\mathrm{E}-\mathrm{U}^{\mathrm{IV}}$ cores $(\mathrm{E}=\mathrm{S}, \mathrm{Se}, \mathrm{Te})$ : implications for determining the presence or absence of actinide-actinide magnetic exchange. Chem. Sci. 8, 6207-6217 (2017).

34. Mills, D. P. et al. A delocalized arene-bridged diuranium single-molecule magnet. Nat. Chem. 3, 454-460 (2011).

35. Selbin, J. \& Ortego, J. D. The chemistry of uranium(V). Chem. Rev. 69, 657-671 (1969).

36. Windorff, C. J. \& Evans, W. J. ${ }^{29} \mathrm{Si}$ NMR spectra of silicon-containing uranium complexes. Organometallics 33, 3786-3791 (2014).

37. Chatelain, L. et al. Terminal uranium(V)-nitride hydrogenations involving direct addition or Frustrated Lewis Pair mechanisms. Nat. Commun. 11, 14221 (2020).

38. Gardner, B. M. \& Liddle, S. T. Uranium triamidoamine chemistry. Chem. Commun. 51, 10589-10607 (2015).

39. Jones, M. T. \& Kuechler, T. C. An electron spin resonance study of the benzene anion radical. A model of its ion pair with alkali metal ions. J. Phys. Chem. 81, 360-367 (1977).

40. Merkel, P. B., Luo, P., Dinnocenzo, J. P. \& Farid, S. Accurate oxidation potentials of benzene and biphenyl derivatives via electron-transfer equilibria and transient kinetics. J. Org. Chem. 74, 5163-5173 (2009).

41. Gardner, B. M. et al. The role of 5 -orbital participation in unexpected inversion of the $\sigma$-bond metathesis reactivity trend of triamidoamine thorium (IV) and uranium(IV) alkyls. Chem. Sci. 5, 2489-2497 (2014).

42. Gardner, B. M. et al. Evidence for single metal two electron oxidative addition and reductive elimination at uranium. Nat. Commun. 8, 1898 (2017).

43. Du, J. et al. Thorium- and uranium-azide reductions: a transient dithorium-nitride versus isolable diuranium-nitrides. Chem. Sci. 10, 3738-3745 (2019).

44. $\mathrm{Du}, \mathrm{J}$. et al. Thorium-nitrogen multiple bonds provide evidence for pushingfrom-below for early actinides. Nat. Commun. 10, 12206-5 (2019).

45. Mougel, V., Biswas, B., Pecaut, J. \& Mazzanti, M. New insights into the acid mediated disproportionation of pentavalent uranyl. Chem. Commun. 46, 8648-8650 (2010).

46. Mougel, V., Horeglad, P., Nocton, G., Pecaut, J. \& Mazzanti, M. Cation-cation complexes of pentavalent uranyl: from disproportionation intermediates to stable clusters. Chem. Eur. J. 16, 14365-14377 (2010). 
47. Nocton, G. et al. Synthesis, structure, and bonding of stable complexes of pentavalent uranyl. J. Am. Chem. Soc. 132, 495-508 (2010).

48. Chatelain, L., Mougel, V., Pecaut, J. \& Mazzanti, M. Magnetic communication and reactivity of a stable homometallic cation-cation trimer of pentavalent uranyl. Chem. Sci. 3, 1075-1079 (2012).

49. Mougel, V., Pecaut, J. \& Mazzanti, M. New polynuclear U(IV)-U(V) complexes from U(IV) mediated uranyl(V) disproportionation. Chem. Commun. 48, 868-870 (2012).

50. Faizova, R., Scopelliti, R., Chauvin, A.-S. \& Mazzanti, M. Synthesis and characterization of a water stable uranyl(V) complex. J. Am. Chem. Soc. 140, 13554-13557 (2018).

51. Mullane, K. C. et al. C-H bond addition across a transient uranium-nitrido moiety and formation of a parent uranium imido complex. J. Am. Chem. Soc. 140, 11335-11340 (2018)

52. Bailey, P. J. et al. The first structural characterisation of a group 2 metal alkylperoxide complex: comments on the cleavage of dioxygen by magnesium alkyl complexes. Chem. Eur. J. 9, 4820-4828 (2003).

53. Sheldrick, G. M. SHELXT-Integrated space-group and crystal structure determination. Acta Cryst. Sect. A 71, 3-8 (2015).

54. CrysAlisPRO version 39.46, Oxford Diffraction /Agilent Technologies UK Ltd, Yarnton, England.

55. Sheldrick, G. M. Crystal structure refinement with SHELXL. Acta Cryst. Sect. C. 71, 3-8 (2015).

56. Dolomanov, O. V., Bourhis, L. J., Gildea, R. J., Howard, J. A. K. \& Puschmann, H. OLEX2: a complete structure solution, refinement and analysis program. J. Appl. Cryst. 42, 339-341 (2009).

57. Farugia, L. J. WinGX and ORTEP for Windows: an update. J. Appl. Cryst. 45, 849-854 (2012).

58. Persistence of Vision (TM) Raytracer, Persistence of Vision Pty. Ltd., Williamstown, Victoria, Australia.

59. Becke, A. D. Density-functional thermochemistry. III. role exact. Exch. J. Chem. Phys. 98, 5648-5652 (1993).

60. Burke, K., Perdew, J. P. \& Wang, Y. Electronic density functional theory: recent progress and new directions; (eds. J. F. Dobson, G. Vignale, M. P. Das) (Plenum, 1998)

61. Frisch, M. J., et al. Gaussian 09 Revision D.01 (Gaussian, Inc, 2016).

62. Küchle, W., Dolg, M., Stoll, H. \& Preuss, H. Energy-adjusted pseudopotentials for the actinides: parameter sets and test calculations for thorium and thorium monoxide. J. Chem. Phys. 100, 7535-7542 (1994).

63. Cao, X., Dolg, M. \& Stoll, H. Valence basis sets for relativistic energy-consistent small-core actinide pseudopotentials. J. Chem. Phys. 118, 487-496 (2003).

64. Cao, X. \& Dolg, M. Segmented contraction scheme for small-core actinide pseudopotential basis sets. J. Molec. Struct. 673, 203-209 (2004).

65. Ditchfield, R., Hehre, W. J. \& Pople, J. A. Self-consistent molecular-orbital methods. IX. An extended Gaussian-type basis for molecular-orbital studies of organic molecules. J. Chem. Phys. 54, 724-728 (1971).

66. Hehre, W. J., Ditchfield, R. \& Pople, J. A. Self-consistent molecular orbital methods. XII. Further extensions of Gaussian-type basis sets for molecular orbital studies of organic molecules. J. Chem. Phys. 56, 2257-2261 (1972).

67. Hariharan, P. C. \& Pople, J. A. The influence of polarization functions on molecular orbital hydrogenation energies. Theor. Chim. Acta 28, 213-222 (1973).

68. Francl, M. M. et al. Self-consistent molecular orbital methods. XXIII. A polarization-type basis set for second-row elements. J. Chem. Phys. 77, 3654-3665 (1982).
69. Marenich, A. V., Cramer, C. J. \& Truhlar, D. G. Universal solvation model based on solute electron density and on a continuum model of the solvent defined by the bulk dielectric constant and atomic surface tensions. J. Phys. Chem. B 113, 6378-6396 (2009).

\section{Acknowledgements}

We gratefully acknowledge funding and support from the UK Engineering and Physical Sciences Research Council (grants EP/K024000/1, EP/M027015/1, EP/P001386/1, EP/ S033181/1), European Research Council (grant CoG612724), Royal Society (grant UF110005), Leverhulme Trust (RF-2018-545\4), Humboldt Foundation, CalMip, The University of Manchester, COST Action CM1006, and the UK National Electron Paramagnetic Resonance Facility.

\section{Author contributions}

J.D. prepared and characterised the complexes. I.D. and L.M. computed and interpreted the reaction profiles. J.A.S. and E.L. recorded and interpreted the magnetic data. F.T. recorded and interpreted the EPR data. A.J.W. collected, solved, and refined all the crystallographic data. S.T.L. assisted with data analysis and directed the research. L.M. and S.T.L. wrote the manuscript with input from all the authors.

\section{Competing interests}

The authors declare no competing interests.

\section{Additional information}

Supplementary information The online version contains supplementary material available at https://doi.org/10.1038/s41467-021-25151-z.

Correspondence and requests for materials should be addressed to L.M. or S.T.L.

Peer review information Nature Communications thanks Laura Pereira and the other, anonymous, reviewer(s) for their contribution to the peer review of this work.

Reprints and permission information is available at http://www.nature.com/reprints

Publisher's note Springer Nature remains neutral with regard to jurisdictional claims in published maps and institutional affiliations.

Open Access This article is licensed under a Creative Commons Attribution 4.0 International License, which permits use, sharing, adaptation, distribution and reproduction in any medium or format, as long as you give appropriate credit to the original author(s) and the source, provide a link to the Creative Commons license, and indicate if changes were made. The images or other third party material in this article are included in the article's Creative Commons license, unles indicated otherwise in a credit line to the material. If material is not included in the article's Creative Commons license and your intended use is not permitted by statutory regulation or exceeds the permitted use, you will need to obtain permission directly from the copyright holder. To view a copy of this license, visit http://creativecommons.org/ licenses/by/4.0/.

(C) The Author(s) 2021 